\title{
高強度䋊維補強モルタルのPC構造物への 適用に関する実験的研究
}

\author{
桜田 道博 1 - 森 拓也 2 - 大山 博明 3 - 関 博4 \\ 1正会員 (株) ピーエス三菱 技術本部 技術研究所（†250-0875 神奈川県小田原市南鴨宮2-1-67） \\ E-mail: m-saku@psmic.co.jp \\ 2正会員（株）ピーエス三菱 技術本部（†104-8215 東京都中央区晴海2-5-24） \\ E-mail: t-mori@psmic.co.jp \\ 3正会員 （株）ピーエス三菱＼cjkstart技術本部＼cjkstart技術部（テ104-8215 東京都中央区晴海2-5-24） \\ E-mail: h_ohyama@psmic.co.jp \\ 4フェロー会員 早稲田大学教授 理工学術院 社会環境工学科（169-8555 東京都新宿区大久保3-4-1）
}

\begin{abstract}
設計基準強度が $120 \mathrm{~N} / \mathrm{mm}^{2}$ の高強度繊維補強モルタルをPC構造物に適用するため, 各種材料試験, PCは り供試体による曲げ載荷実験およびせん断載荷実験を行った。材料試験では高強度繊維補強モルタルの圧 縮強度, 引張強度, ヤング係数, クリープ係数, 乾燥収縮ひずみなど, PC構造物の設計に必要な材料特性 を明らかにした。一方，曲げ載荷実験およびせん断載荷実験では，PCはり供試体の曲げひび割れ発生モー メント，曲げ耐力およびせん断耐力などの構造特性が既往の設計方法で安全側に評価できることを確認し た。これらの結果から高強度繊維補強モルタルのPC構造物への適用は十分可能であることが示された.
\end{abstract}

Key Words : high strength fiber reinforced mortar, creep, drying shrinkage, diffusion coefficient of chloride ions, prestressed concrete beam, flexural strength, shear strength

\section{1. はじめに}

近年, セメントや化学混和剂等の高性能化などにより, 設計基準強度が $150 \mathrm{~N} / \mathrm{mm}^{2}$ 以上の高強度コンクリートが 実用化されている 1), 2). 高強度コンクリートにおいて粗 骨材は流動性の低下，強度のばらつき，強度の頭打ち現 象などの原因となることがあり，高強度になるほど粗骨 材を峳選する必要がある ${ }^{3)}$ ，そこで，高強度を実現する 一つの方法として，粗骨材を使用しないこと，さらに高 強度材料の物性を改善するため鋼繊維を混入することを 考え, 鋼䋊維を混入したセメント系の高強度材料(以降, 高強度繊維補強モルタル)を開発することとした(写真-1,

\section{写真-2).}

高強度䋊維補強モルタルは, 粗骨材を使用しないため, 骨材をそれほど㛜選することなく，優れた流動性，自己 充填性および設計基準強度 $120 \mathrm{~N} / \mathrm{mm}^{2}$ の高強度が得られ る.また，鋼繊維を混入していることから自己収縮等に よるひび割れを防止することや高強度コンクリート特有 の脆性的な破壊を抑制することが可能になる ${ }^{4)}$. 既に, 粗骨材を使用せず，鋼䋊維を混入した高強度材料として
超高強度繊維補強コンクリート(以降，UFC)が開発され ているが 5) 9), 高強度䋊維補強モルタルは, UFC ほど高 強度ではないこと，部材に鉄筋を配置し鋼繊維の混入量 を少なくしたこと，蒸気養生を簡素化したことなどが UFC と異なっている.

このような高強度繊維補強モルタルをプレストレスト コンクリート(以降， PC)構造物に適用することにより， 桁高が支間の 1/35 以下となる低桁高 PC 橋(写真-3)や高 さ 40m のアンテナ塔(写真-4)など, 通常の強度のコンク リートでは実現できない付加価值の高い PC 構造物を比 較的安価に実現できるが ${ }^{4)}$, 高強度䋊維補強モルタルを PC 構造物に適用するにあたっては，材料の設計值や， PC 部材としての構造性能を明確にする必要があった. そ こで, 各種材料試験, PC はりの曲げ載荷試験, せん断載 荷試験などを実施し，設計に必要な材料特性と PC 部材 としての構造性能を確認することとした ${ }^{4), 10), 11)}$.この論 文では，これまでに行った試験の最新の結果を示すとと もに，曲げ耐力算出時の応力一ひずみ曲線，曲げひび割 れ幅，およびせん断耐力などに関して得られた新たな知 見を示した. 


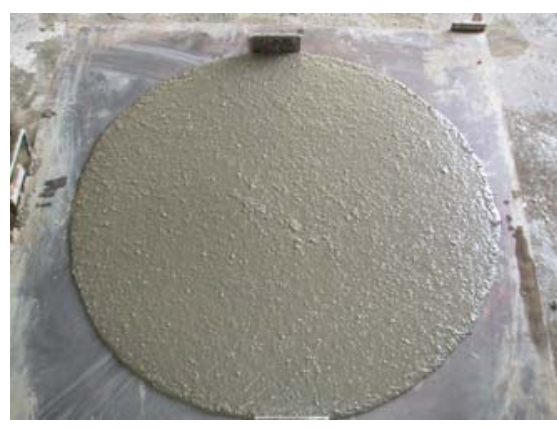

写真-1 高強度繊維補強モルタル

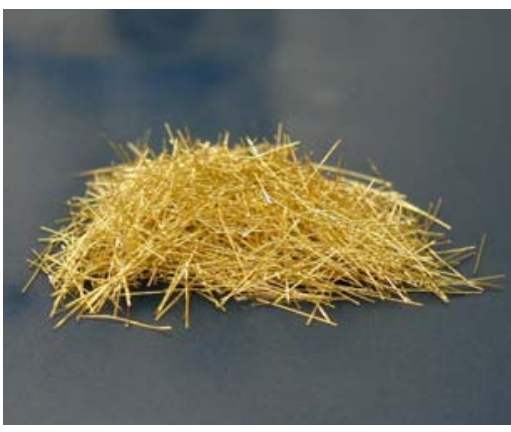

写真-2 鋼繊維
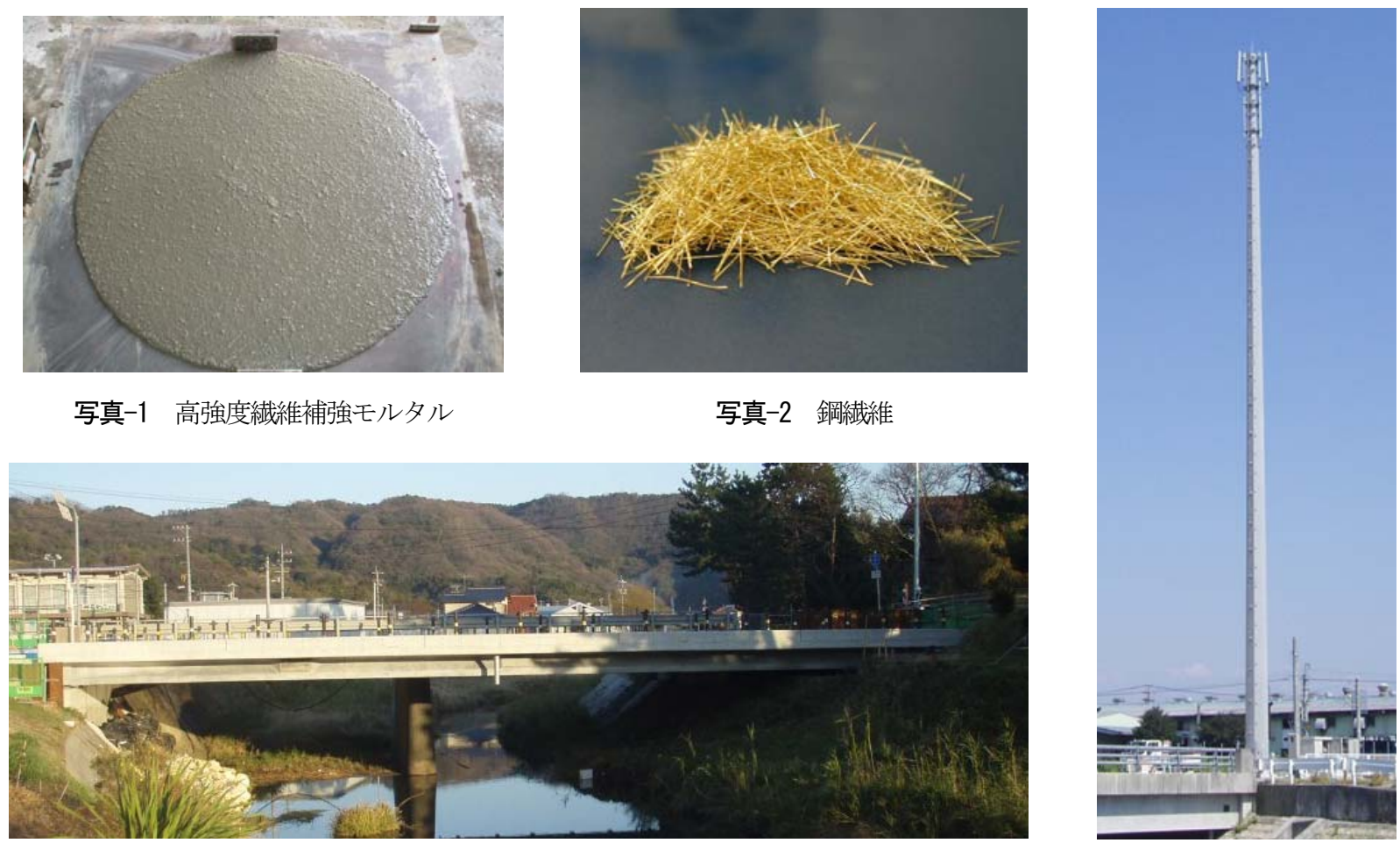

写真-3 低桁高 PC 橋への適用例

写真-4 アンテナ塔への適用例

\section{2. 高強度繊維補強モルタルの開発}

\section{(1) 開発の背景}

1990 年代，フランスにおいて圧縮強度が 200N/mm² 超える反応性粉体コンクリート(以降，RPC)が開発され， 原子力発電プラントのはりや, 橋りょうに適用された ${ }^{12)}$. RPC は UFC として日本にも導入され, 歩道橋, 道路橋 および海洋構造物などに適用され，PC 構造物の軽量化， 林高の低減，支間の長大化，高而久性化が可能になった と報告されている ${ }^{13), 14), 15)}$ 。このように高強度材料を PC 構造物に適用することで，普通強度のコンクリートでは 実現できない付加価值の高い PC 構造物を実現できるこ とから，比較的安価な高強度䋊維補強モルタルを開発す ることとした.

\section{(2) 開発方針}

高強度䋊維補強モルタルは経済性を考慮し, 通常のコ ンクリート用の製造設備で水，セメント，細骨材などを 計量した後, バッチミキサで練り混ぜるノンプレミック ス方式で製造することとした．また，セメントには高強 度コンクリート用のセメントとして実績のあるシリカフ ユーム混入セメントを, 細骨材にはJIS A 5308 附属書 1 に適合する通常のコンクリート用のものを使用すること とした．養生方法に関しては，早期に強度を発現させる こと，およびクリープ・乾燥収縮によるプレストレスの 低下を最小限にすることを目的として, 蒸気養生を行う こととした.
（3）高強度繊維補強モルタルの開発

\section{a) 試験方法}

高強度繊維補強モルタルの開発にあたっては，最初に 配合を決定するための事前試験を行った。事前試験では 表-1 の試験を実施し, 高強度䋊維補強モルタルの設計基 準強度, 水セメント比 W/C, 単位水量, 細骨材の種類, 鋼繊維の種類および混入率を決定した。事前試験におけ る使用材料および配合をそれぞれ, 表-2 および表-3に示 す. モルタルの配合は，空気量を $2.0 \%$ に設定し，W/C, 単位水量, 細骨材の種類, 鋼䋊維の種類および混入率を パラメータとした 14 種類とした. 鋼䋊維は外割で混入し, その混入率はモルタルに対する体積百分率とした.

モルタルの練混ぜ方法および蒸気養生の養生方法をそ れぞれ，図-1 および図-2 に示す. 蒸気養生の前置き期間 は, 高強度䋊維補強モルタルの凝結試験の結果(始発 19.5 時間，終結 22.5 時間)から 24 時間以上と決定した. これ は遅れエトリンガイトの生成を避けるため, 凝結が終結 するまでは蒸気養生を行うべきではないと考えたためで ある ${ }^{16)}$ 。ただし, 凝結終結時には強度が発現しておらず 脱枠できないため, 型枠を脱枠した後に蒸気養生する場 合は，前置き期間を 48 時間まで長くすることとした. 最 高温度および最高温度の保持期間に関しては UFC の標

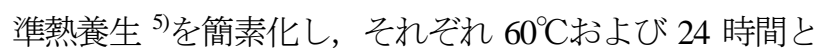
した.

\section{b) 事前試験の結果}

事前試験の結果の一覧を表-4に示す.これらの結果に 基づき高強度繊維補強モルタルの配合を検討した。 
表-1 事前試験での試験項目

\begin{tabular}{l|l|l}
\hline \multicolumn{1}{c|}{ 試験項目 } & 試験方法 & \multicolumn{1}{|c}{ 備 考 } \\
\hline (1) フロー試験 $(0$ 打 $)$ & JIS R 5201 & 落下なし \\
\hline (2) スランプフロー試験 & JIS A 1150 & \\
\hline (3) 空気量試験 & JIS A 1128 & 圧力法 \\
\hline (4) 圧縮強度試験 & JSCE-G505 & 円柱供試体 $(\phi 5 \times 10 \mathrm{~cm})$ \\
\cline { 2 - 3 } & JIS A 1108 & 円柱供試体 $(\phi 10 \times 20 \mathrm{~cm})$ \\
\hline (5) 曲げ強度試験 & JIS A 1106 & 角柱供試体 $(4 \times 4 \times 16 \mathrm{~cm})$ \\
\hline
\end{tabular}

表-2 使用材料

\begin{tabular}{|c|c|c|}
\hline 材 料 & 記号 & 仕 様 \\
\hline セメント & $\mathrm{C}$ & シリカフューム混入セメント, 密度 $3.08 \mathrm{~g} / \mathrm{cm}^{3}$ \\
\hline 水 & $\mathrm{W}$ & 上水道水 \\
\hline \multirow{4}{*}{ 細骨材 } & \multirow{4}{*}{ S } & $\begin{array}{l}\text { 砕砂-1(岩間産), 表乾密度 } 2.68 \mathrm{~g} / \mathrm{cm}^{3} \text {, 吸水率 } \\
1.04 \% \text {, F.M.2.82 }\end{array}$ \\
\hline & & $\begin{array}{l}\text { 山砂(麻生产), 表乾密度 } 2.60 \mathrm{~g} / \mathrm{cm}^{3} \text {, 吸水率 } 2.47 \% \text {, } \\
\text { F.M.2.91 }\end{array}$ \\
\hline & & $\begin{array}{l}\text { 砕砂-2(東根市産), 表乾密度 } 2.57 \mathrm{~g} / \mathrm{cm}^{3} \text {, 吸水率 } \\
\text { 2.59\%, F.M.2.95 }\end{array}$ \\
\hline & & 珪砂(鹿沼产), 絶乾密度 $2.60 \mathrm{~g} / \mathrm{cm}^{3}$ \\
\hline \multirow{2}{*}{ 鋼繊維 } & \multirow{2}{*}{ SF } & $\begin{array}{l}\text { 高張力鋼, 引張強度 } 2000 \mathrm{~N} / \mathrm{mm}^{2} \text { 以上, 長さ } 13 \mathrm{~mm} \text {, } \\
\text { 径 } 0.16 \mathrm{~mm} \text {, 密度 } 7.85 \mathrm{~g} / \mathrm{cm}^{3}\end{array}$ \\
\hline & & $\begin{array}{l}\text { ステンレス鋼, 引張強度 } 400 \mathrm{~N} / \mathrm{mm}^{2} \text {, 長さ } 22 \mathrm{~mm} \text {, } \\
\text { 径 } 0.6 \mathrm{~mm} \text {, 密度 } 7.85 \mathrm{~g} / \mathrm{cm}^{3}\end{array}$ \\
\hline 高性能減水剤 & SP & ポリカルボン酸系 \\
\hline
\end{tabular}

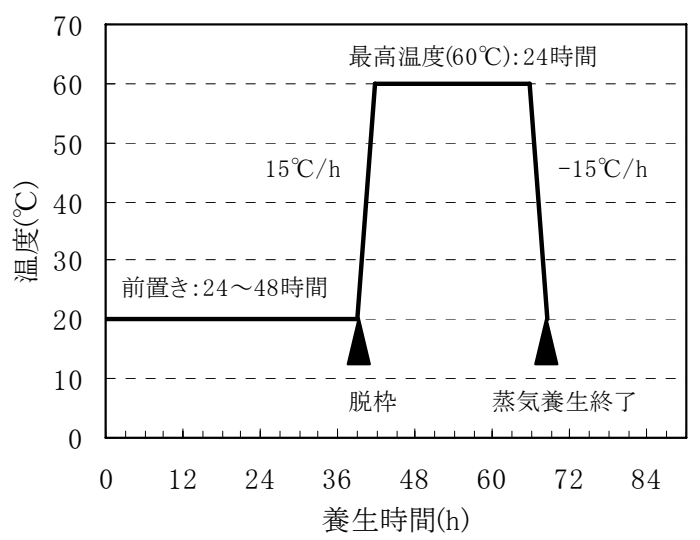

図-2 養生方法

\section{c）設計基準強度および水セメント比の決定}

蒸気養生終了後の材齢 3 日におけるセメント水比 $\mathrm{C} / \mathrm{W}$ と圧縮強度との関係を図-3に示す。一般に，鋼䋊維が圧 縮強度に及ぼす影響は小さいとされていることから ${ }^{17)}$, ここでは鋼繊維を混入していないモルタルで検討した.

図-3 に示すようにモルタルの圧縮強度は細骨材の種類 の影響を受け，山砂を使用すると圧縮強度が低下するこ とが確認されたため，高強度䋊維補強モルタルには砕砂 のみを使用することとした，なお，珪砂を使用しても高 い強度は得られたが，コストの面から砕砂とした。

一方，砕砂のみを使用した場合でも圧縮強度は $150 \mathrm{~N} / \mathrm{mm}^{2}$ 程度で頭打ちとなっている。このため，一般 のコンクリート用の細骨材を用いた高強度䋊維補強モル タルでは，圧縮強度のばらつきを考慮すると，設計基準
表-3 事前試験における配合

\begin{tabular}{|c|c|c|c|c|c|c|c|c|}
\hline No. & $\begin{array}{l}\text { W/C } \\
(\%)\end{array}$ & $\begin{array}{l}\text { Air } \\
(\%)\end{array}$ & \begin{tabular}{|c|} 
SF \\
混入率 \\
(vol.\%)
\end{tabular} & $\begin{array}{c}\text { SF } \\
\text { 種類 } \\
\end{array}$ & $\begin{array}{l}\text { 細骨材 } \\
\text { 種類* } \\
\end{array}$ & $\begin{array}{c}\mathrm{W} \\
\left(\mathrm{kg} / \mathrm{m}^{3}\right)\end{array}$ & $\begin{array}{c}\mathrm{C} \\
\left(\mathrm{kg} / \mathrm{m}^{3}\right)\end{array}$ & $\begin{array}{c}\mathrm{S} \\
\left(\mathrm{kg} / \mathrm{m}^{3}\right)\end{array}$ \\
\hline 1-1 & \multirow{8}{*}{17} & \multirow{14}{*}{2.0} & 0 & - & 砕砂-1 & 210 & 1313 & 922 \\
\hline $1-2$ & & & 0 & - & 山砂 & 210 & 1313 & 908 \\
\hline $1-3$ & & & 1.0 & 高張力鋼 & 砕砂-2 & 200 & 1176 & 1023 \\
\hline $1-4$ & & & 0 & - & 砕砂-1 & 210 & 1235 & 989 \\
\hline $1-5$ & & & 0 & - & 砕砂-2 & 210 & 1235 & 948 \\
\hline $1-6$ & & & 1.0 & 高張力鋼 & 砕砂-2 & 210 & 1235 & 948 \\
\hline $1-7$ & & & 2.0 & 高張力鋼 & 砕砂-2 & 210 & 1235 & 948 \\
\hline $1-8$ & & & 0 & - & 山砂 & 210 & 1235 & 974 \\
\hline $1-9$ & \multirow{2}{*}{20} & & 0 & - & \begin{tabular}{|l|} 
砕砂-1 \\
\end{tabular} & 200 & 1000 & 1219 \\
\hline $1-10$ & & & 0 & - & 山砂 & 200 & 1000 & 1201 \\
\hline 1-11 & \multirow{2}{*}{23} & & 0 & - & 砕砂-1 & 200 & 870 & 1335 \\
\hline $1-12$ & & & 0 & - & 山砂 & 200 & 870 & 1315 \\
\hline $1-13$ & 20 & & 1.0 & 高張力鋼 & 珪砂 & 215 & 1075 & 1082 \\
\hline $1-14$ & 22 & & 4.0 & ステンレス鋼 & 珪砂 & 232 & 1055 & 1053 \\
\hline
\end{tabular}

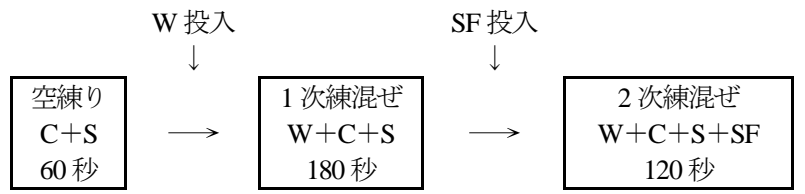

図-1＼cjkstart練混ぜ方法

表-4 事前試験の結果

\begin{tabular}{|c|c|c|c|c|c|c|c|}
\hline \multirow[b]{2}{*}{ No. } & \multirow[b]{2}{*}{$\begin{array}{l}\text { W/C } \\
(\%)\end{array}$} & \multirow[b]{2}{*}{$\begin{array}{l}\text { フロー } \\
(\mathrm{mm})\end{array}$} & \multirow{2}{*}{$\begin{array}{c}\text { スランプ } \\
\text { フロー } \\
(\mathrm{mm})\end{array}$} & \multirow[b]{2}{*}{$\begin{array}{c}\text { 空気量 } \\
(\%)\end{array}$} & \multicolumn{2}{|c|}{ 圧縮強度 } & \multirow[b]{2}{*}{$\begin{array}{c}\text { 曲げ強度 } \\
\left(\mathrm{N} / \mathrm{mm}^{2}\right)\end{array}$} \\
\hline & & & & & $\begin{array}{c}\text { 材齢 } 3 \text { 日 } \\
\left(\mathrm{N} / \mathrm{mm}^{2}\right)\end{array}$ & \begin{tabular}{|c|} 
材齢 28 日 \\
$\left(\mathrm{N} / \mathrm{mm}^{2}\right)$ \\
\end{tabular} & \\
\hline $1-1$ & \multirow{2}{*}{16} & 252 & - & 3.2 & 151 & 160 & - \\
\hline $1-2$ & & 230 & - & 3.2 & 147 & 151 & - \\
\hline $1-3$ & \multirow{6}{*}{17} & 250 & 660 & 2.9 & 159 & 163 & - \\
\hline $1-4$ & & 262 & - & 3.1 & 150 & 159 & - \\
\hline $1-5$ & & 250 & 740 & 2.9 & 161 & 166 & 10.0 \\
\hline $1-6$ & & 250 & 730 & 3.2 & 154 & 154 & 19.3 \\
\hline $1-7$ & & 175 & 550 & 2.2 & 153 & 164 & 24.9 \\
\hline $1-8$ & & 280 & - & 2.4 & 141 & 152 & - \\
\hline $1-9$ & \multirow{2}{*}{20} & 291 & - & 2.0 & 135 & 143 & - \\
\hline $1-10$ & & 310 & - & 1.6 & 122 & 140 & - \\
\hline $1-11$ & \multirow{2}{*}{23} & 303 & - & 1.5 & 124 & 134 & - \\
\hline $1-12$ & & 329 & - & 2.0 & 101 & 116 & - \\
\hline $1-13$ & 20 & 261 & - & - & 178 & - & 23.7 \\
\hline $1-14$ & 22 & 262 & - & - & 160 & - & 26.8 \\
\hline
\end{tabular}

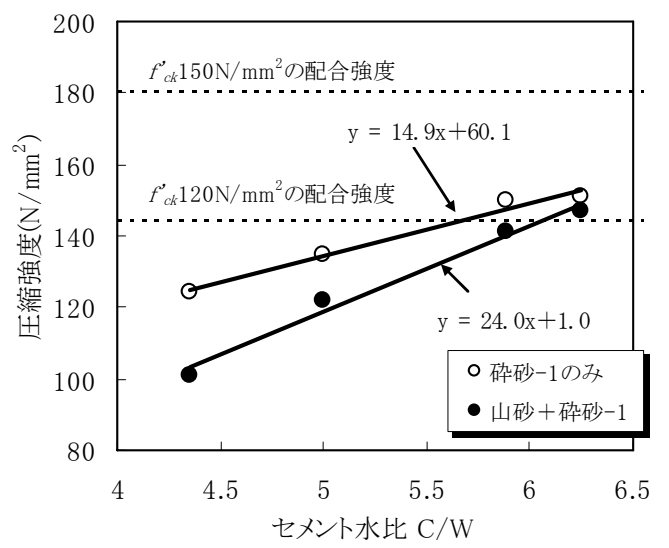

図-3 セメント水比 $\mathrm{C} / \mathrm{W}$ と圧縮強度との関係 
強度を $150 \mathrm{~N} / \mathrm{mm}^{2}$ 以上とすることは困難であると考えら れた.したがって, 高強度繊維補強モルタルの設計基準 強度は $120 \mathrm{~N} / \mathrm{mm}^{2}$ に設定することとし，これを満足する 配合強度を, 変動係数を $10 \%$ と仮定してコンクリート標 準示方書 ${ }^{18)}$ に準拠して算出すると $144 \mathrm{~N} / \mathrm{mm}^{2}$ となる. 配 合強度 $144 \mathrm{~N} / \mathrm{mm}^{2}$ を満足する C/W 高強度繊維補強モルタルの W/C は 17\%にすることとし た。

\section{d) 単位水量の決定}

W/C が 17\%で鋼繊維を 1.0vol.\%混入した場合の単位水 量とスランプフローとの関係は図-4 に示すとおりであ り，単位水量が大きいほどスランプフローが大きくなっ た. 単位水量およびスランプフローは施工できる範囲で なるべく小さくする必要があるが，単位水量が $200 \mathrm{~kg} / \mathrm{m}^{3}$ では粘性が高いうえ, 写真-5に示すとおりファイバーボ 一ルも発生したため均質性が確保できないと判断された. 一方，単位水量が $210 \mathrm{~kg} / \mathrm{m}^{3}$ では過度な粘性，材料分離お よびファイバーボールは認められず，施工性は良好と判 断された。したがって, 高強度繊維補強モルタルの単位 水量は $210 \mathrm{~kg} / \mathrm{m}^{3}$ とし，スランプフローは $750 \mathrm{~mm}$ 程度を 標準とすることとした.

\section{e) 鋼繊維種類の決定}

鋼纎維の混入率と曲げ強度を表-5 に示す. No.1-13の 配合では引張強度が $2000 \mathrm{~N} / \mathrm{mm}^{2}$ の高張力鋼の鋼繊維を 1.0vol.\%混入し， No.1-14 の配合では引張強度が $400 \mathrm{~N} / \mathrm{mm}^{2}$ のステンレス鋼の鋼繊維を 4.0vol.\%混入した. また，単位水量はモルタルのフロー(JIS R 5201)がともに $260 \mathrm{~mm}$ 程度となるよう決定した．表-5 からわかるとお り，高張力鋼の鋼繊維を $1.0 \mathrm{vol}$ \%混入した場合とステン レス鋼の鋼繊維を 4.0vol.\%混入した場合の曲げ強度は同 程度であり, 鋼䋊維の引張強度が高いほど混入率を小さ くでき，単位水量も少なくなることがわかる．したがっ て，少ない混入率で高い曲げ強度が得られる高張力鋼の 鋼繊維を高強度繊維補強モルタルに使用することとした。 なお，鋼繊維の長さは一般に，骨材最大径の 2 倍以上が 推奨されているが ${ }^{17)}$, 長すぎると施工性が低下するため, メーカーの製品の中から細骨材の最大寸法 $(5 \mathrm{~mm})$ の 2 倍 以上で，最も短い鋼綫維(長さ $13 \mathrm{~mm})$ を選択した。

\section{f) 鋼繊維の混入率の決定}

W/C が $17 \%$, 単位水量が $210 \mathrm{~kg} / \mathrm{m}^{3}$ の場合の鋼䋊維の 混入率とスランプフローとの関係を図-5 に示す. 鋼繊維 混入率 $0 \mathrm{vol} . \% ， 1.0 \mathrm{vol} . \%$ よび 2.0vol.\%におけるスラン プフローはそれぞれ，740mm，730mm および550mm で

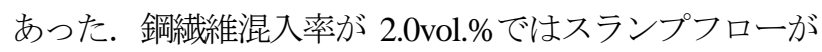
大きく低下し, 粘性も過大で施工は困難と判断されたが, 鋼繊維混入率が $1.0 \mathrm{vol} \%$ \%ま゙はスランプフローの低下は わずかであり，充填性および材料分離抵抗性の面で施工 性は良好と判断された。 したがって, 鋼繊維混入率の上

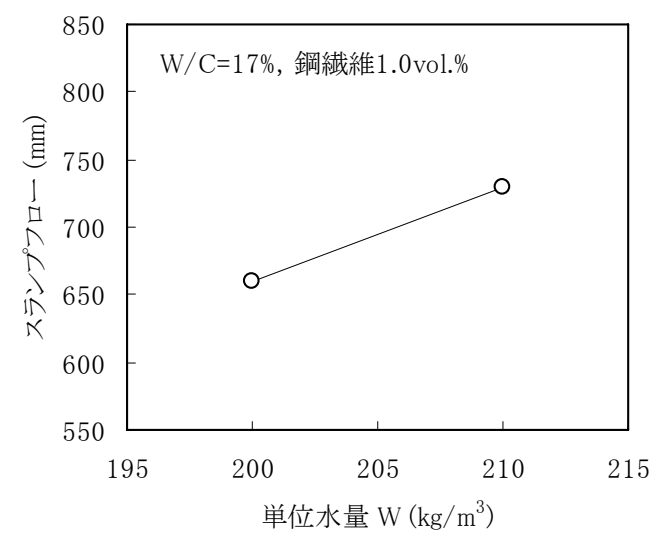

図-4 単位水量とスランプフローとの関係

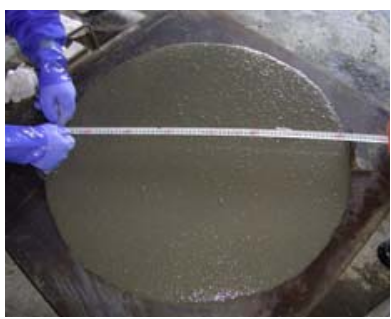

a) 単位水量 $210 \mathrm{~kg} / \mathrm{m}^{3}$

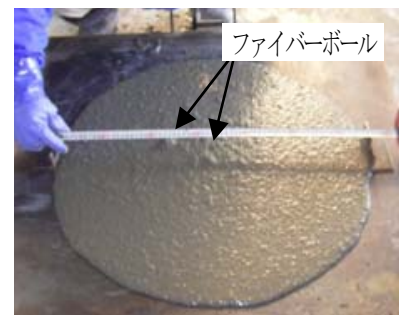

b) 単位水量 $200 \mathrm{~kg} / \mathrm{m}^{3}$
写真-5 スランプフロー試験の状況

表-5 鋼繊維の混入率と曲げ強度

\begin{tabular}{c|c|c|c|c|c|c|c}
\hline & $\begin{array}{c}\mathrm{W} / \mathrm{C} \\
(\%)\end{array}$ & $\begin{array}{c}\mathrm{W} \\
\left(\mathrm{kg} / \mathrm{m}^{3}\right)\end{array}$ & $\begin{array}{c}\text { 鋼繊維 } \\
\text { 種類 }\end{array}$ & $\begin{array}{c}\text { 鋼繊維 } \\
\text { 引張強度 } \\
\left(\mathrm{N} / \mathrm{mm}^{2}\right)\end{array}$ & $\begin{array}{c}\text { 鋼繊維 } \\
\text { 混入率 } \\
(\mathrm{vol} \%)\end{array}$ & $\begin{array}{c}\text { 圧縮強度 } \\
\left(\mathrm{N} / \mathrm{mm}^{2}\right)\end{array}$ & $\begin{array}{c}\text { 曲げ強度 } \\
\left(\mathrm{N} / \mathrm{mm}^{2}\right)\end{array}$ \\
\hline $1-13$ & 20 & 215 & 高張力鋼 & 2000 & 1.0 & 178 & 23.7 \\
\hline $1-14$ & 22 & 223 & ステンレス鋼 & 400 & 4.0 & 160 & 26.8 \\
\hline
\end{tabular}

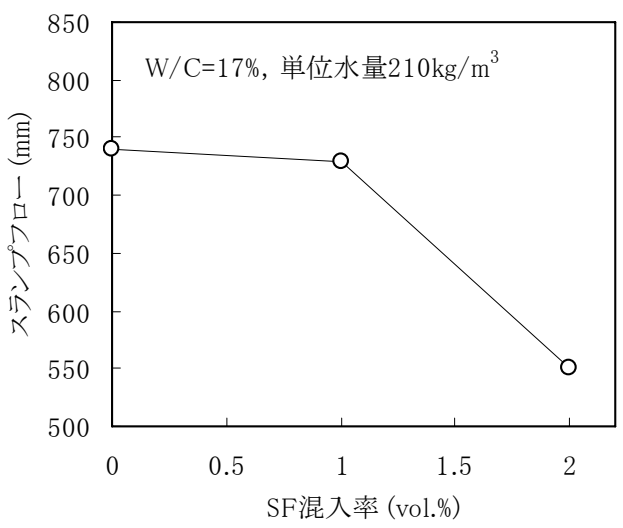

図-5 鋼繊維混入率とスランプフローとの関係

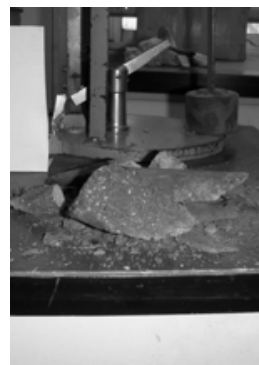

鋼繊維 0.0vol.\%

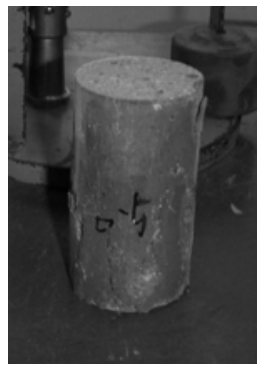

鋼繊維 0.5vol.\%

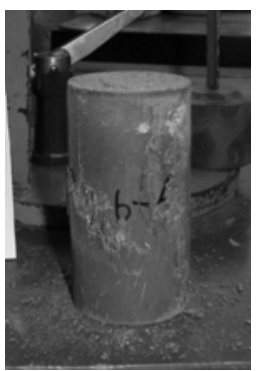

鋼䋐維 1.0vol.\%
写真-6 圧縮強度試験後の供試体 
限は $1.0 \mathrm{vol}$ \%とした。一方，鋼繊維混入率の下限は，収 縮ひび割れに対する抵抗性と圧縮破壊時の状態で決定す ることとした，後述するせん断載荷試験の供試体で，鋼 繊維を混入していないものは載荷試験前に収縮ひび割れ が発生(図-27 の点線)したのに対し, 鋼䋊維を 0.5vol.\%混 入したものに関してはひび割れが発生しておらず，ひび 割れ抑制効果があることが確認された。 また，セメント 系の高強度材料は圧縮破壊時に爆裂寸る傾向にあるが,

写真-6 に示寸とおり，鋼繊維を $0.5 \mathrm{vol} . \%$ を混入した場合 は圧縮破壊時の爆裂は発生していない，したがって，鋼 繊維混入率の下限值は $0.5 \mathrm{vol} . \%$ とすることとした.

\section{g) 高強度繊維補強モルタルの配合}

以上の結果から高強度繊維補強モルタルの使用材料お よび配合は次のとおりとし，決定した配合を表-6に示寸。

1) 細骨材には砕砂を使用する.

2) 設計基準強度は $120 \mathrm{~N} / \mathrm{mm}^{2}$ とし, W/Cは $17 \%$ とする.

3) 単位水量は $210 \mathrm{~kg} / \mathrm{m}^{3}$ とし, スランプフローは 750mm を標準とする.

4) 鋼繊維の種類は高張力鋼とし, その混入率は $0.5 \sim$ 1.0vol.\%とする.

\section{3. 高強度䋊維補強モルタルの材料特性}

\section{(1) 試験方法}

開発した高強度繊維補強モルタルを実際のPC 構造物 に適用するには，圧縮強度のほか，ヤング係数，引張強 度, クリープ係数, 乾燥収縮ひずみなど, 設計に必要な 材料特性を把握する必要があった，また，中性化，凍結 融解および塩害に対する抵抗性など，耐久性に関する性 状も確認寸る必要があった. そこで，表-7 に示寸材料試 験を行い, 2 章で決定した高強度繊維補強モルタルの材 料特性を確認することとした。

\section{a) 使用材料および配合}

材料試験における使用材料は表-2 と同様とした. ただ し，高強度繊維補強モルタルに対応できる製品工場が限 定されたことから，細骨材には東根産の砕砂-2を使用す ることとした．また，鋼䋊維には事前試験で選定した高 張力鋼を使用することとした. 配合は表-8 のとおりとし， 鋼繊維の混入率が異なる 4 種類とした. 練混ぜ方法およ び養生方法はそれぞれ，図-1および図-2 と同様とした.

\section{b) 各種強度試験}

強度試験として, 圧縮強度試験(JIS A 1108), 静弾性係 数試験(JIS A 1149), 割裂引張強度試験(JIS A 1113)および 曲げ強度試験(JIS A 1106)を行った.

c) クリープ試験

クリープ試験はJIS 原案(コンクリートの圧縮クリープ 試験方法案)を準用して行った ${ }^{19}$. クリープ試験供試体を 表-6＼cjkstart決定した高強度䋊維補強モルタルの配合

\begin{tabular}{|c|c|c|c|c|c|c|c|c|}
\hline \multirow[b]{2}{*}{$\begin{array}{c}f_{c k}^{\prime} \\
\left(\mathrm{N} / \mathrm{mm}^{2}\right)\end{array}$} & \multirow{2}{*}{$\begin{array}{c}\text { スランプ } \\
\text { フロー } \\
(\mathrm{mm})\end{array}$} & \multirow[b]{2}{*}{$\begin{array}{l}\text { W/C } \\
(\%)\end{array}$} & \multirow[b]{2}{*}{$\begin{array}{l}\text { Air } \\
(\%) \\
\end{array}$} & \multirow{2}{*}{$\begin{array}{c}\text { SF } \\
\text { 混入率 } \\
\text { (vol.\%) } \\
\end{array}$} & \multicolumn{4}{|c|}{ 単位量 } \\
\hline & & & & & $\begin{array}{c}\mathrm{W} \\
\left(\mathrm{kg} / \mathrm{m}^{3}\right)\end{array}$ & $\begin{array}{c}\mathrm{C} \\
\left(\mathrm{kg} / \mathrm{m}^{3}\right) \\
\end{array}$ & \begin{tabular}{|c|}
$\mathrm{S}$ \\
$\left(\mathrm{L} / \mathrm{m}^{3}\right)$ \\
\end{tabular} & $\begin{array}{c}\mathrm{SF} \\
\left(\mathrm{kg} / \mathrm{m}^{3}\right)\end{array}$ \\
\hline 120 & $750 \pm 100$ & 17 & 2.0 & $0.5 \sim 1.0$ & 210 & 1235 & 369 & $40 \sim 80$ \\
\hline
\end{tabular}

\section{表-7 材料試験における試験項目}

\begin{tabular}{l|c|l}
\hline \multicolumn{1}{c|}{ 試験項目 } & 試験方法 & 備 考 \\
\hline$(1)$ 圧縮強度試験 & JIS A 1108 & 円柱供試体 $(\phi 10 \times 20 \mathrm{~cm})$ \\
\hline$(2)$ 静弾性係数試験 & JIS A 1149 & コンプレッソメータ使用 \\
\hline$(3)$ 割裂引張強度試験 & JIS A 1113 & 円柱供試体 $(\phi 10 \times 20 \mathrm{~cm})$ \\
\hline$(4)$ 曲げ強度試験 & JIS A 1106 & 角柱供試体 \\
\hline (5) クリーブ試験 & JIS 原案 & \\
\hline$(6)$ 乾燥收縮試験 & JIS A 1129 & \\
\hline (7) 促進中性化試験 & JIS A 1153 & \\
\hline$(8)$ 凍結融解試験 & JIS A 1148(A 法 $)$ & 水中凍結水中融解 \\
\hline (9) 塩分拡散係数試験 & JSCE-G572 & 浸せき法 \\
\hline
\end{tabular}

表-8 材料試験における配合

\begin{tabular}{|c|c|c|c|c|c|c|c|c|c|}
\hline \multirow[b]{2}{*}{$\begin{array}{l}\text { 配合 } \\
\text { No. }\end{array}$} & \multirow{2}{*}{$\begin{array}{c}\text { スランプ } \\
\text { フロー } \\
(\mathrm{mm})\end{array}$} & \multirow[b]{2}{*}{$\begin{array}{l}\text { W/C } \\
(\%)\end{array}$} & \multirow[b]{2}{*}{$\begin{array}{l}\text { Air } \\
\text { (\%) }\end{array}$} & \multirow{2}{*}{$\begin{array}{c}\text { SF } \\
\text { 混入率 } \\
\text { (vol.\%) }\end{array}$} & \multicolumn{4}{|c|}{ 単位量 $\left(\mathrm{kg} / \mathrm{m}^{3}\right)$} & \multirow[b]{2}{*}{$\begin{array}{c}\text { SP/C } \\
(\%)\end{array}$} \\
\hline & & & & & W & C & S & SF & \\
\hline $2-1$ & \multirow{3}{*}{$750 \pm 100$} & \multirow{4}{*}{17} & \multirow{4}{*}{2.0} & 0.0 & \multirow{4}{*}{210} & \multirow{4}{*}{1235} & \multirow{4}{*}{948} & 0 & \multirow{4}{*}{3.0} \\
\hline $2-2$ & & & & 0.5 & & & & 40 & \\
\hline $2-3$ & & & & 1.0 & & & & 80 & \\
\hline $2-4$ & $550 \pm 100$ & & & 2.0 & & & & 160 & \\
\hline
\end{tabular}

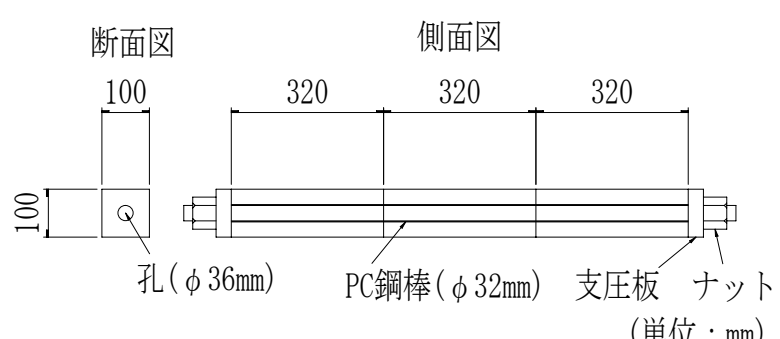

図-6 クリープ試験供試体

図-6 に示す．供試体は，一辺が 100mm の正方形断面で 長さが 320mm の角柱とし, 断面の中心に PC 鋼棒を貫通 させるための孔 $(\phi 36 \mathrm{~mm})$ をあけた. 荷重は, 孔に貫通さ せた PC 鋼棒 $(\phi 32 \mathrm{~mm})$ により 3 体一組で載荷し, 載荷荷 重は約 $450 \mathrm{kN}$ とした. この載荷荷重は, 供試体に発生す る圧縮応力度が載荷時の圧縮強度 $\left(150 \mathrm{~N} / \mathrm{mm}^{2}\right)$ の $1 / 3$ にな るように決定した. 載荷は, 蒸気養生終了後の材齢 3 日 から行った. 載荷荷重の管理は PC 鋼棒に貼付したひず みゲージにより行い，ひずみゲージの值が初期值に対し 土2\%以内となるよう定期的に再緊張して調整した. 供試 体のひずみはコンタクトゲージにより測定した.

\section{d) 乾燥収縮試験}

乾燥収縮試験は，JIS A 1129 に準拠して行った. 供試 体は，クリープ試験と同様とし，供試体断面の中心部に は直径 $36 \mathrm{~mm}$ の孔をあけた。 これは，供試体の乾燥状態 をクリープ試験と同一にするためである．乾燥収縮ひず みは蒸気養生終了後の材齢 3 日より測定を開始した. 


\section{e) 促進中性化試験}

促進中性化試験は JIS A 1153 に準拠して行った。供試 体は，一辺が $100 \mathrm{~mm}$ の正方形断面で，長さが $400 \mathrm{~mm}$ の 角柱とし, 蒸気養生終了後, 温度 $20^{\circ} \mathrm{C}$, 相対湿度 $60 \%$ の 恒温恒湿室に 4 週間静置した後に中性化を促進させた. 促進中性化の条件は, 温度 $20^{\circ} \mathrm{C}$, 相対湿度 $60 \%, \mathrm{CO}_{2}$ 濃度 5\%とした。

\section{f) 凍結融解試験}

凍結融解試験は JIS A 1148 に準拠した。供試体は一辺 が 100mm の正方形断面で長さが 400mm の角柱とし, 蒸 気養生終了後, 4 週間 $20^{\circ} \mathrm{C}$ の水中で養生した後に凍結融 解試験を行った. 試験条件は水中凍結水中融解の A 法と した. 所定のサイクルになった段階で, 供試体の相対動 弾性係数と質量減少量を測定した.

\section{g) 塩分拡散係数試験}

見掛けの塩分拡散係数は JSCE-G572-2003(浸漬による コンクリート中の塩化物イオンの見掛けの拡散係数試験 方法案)に準拠して求めた。供試体は直径 $100 \mathrm{~mm}$, 高さ $200 \mathrm{~mm}$ の円柱とし, 供試体の上下 $25 \mathrm{~mm}$ を切断し, 試験 面以外をエポキシ樹脂でコーティングした後に $10 \%$ の塩 化ナトリウム水溶液に 26 ケ月浸漬した. 26 ケ月後のモ ルタル中の塩化物イオン濃度を蛍光 X 線分析装置(XRF) により測定し，見掛けの塩分拡散係数を求めた.

\section{（2）強度特性}

\section{a) 各種強度試験結果}

材料試験における各種強度試験結果の一覧を表 -9 に 示す，一部，後述する曲げ載荷試験およびせん断載荷実 験の試験結果も含んでいる。 これらの結果を基に高強度 䋊維補強モルタルの強度特性を検討した.

\section{b) ヤング係数}

高強度繊維補強モルタルの応力とひずみとの関係を図 -7 に示寸. 通常のコンクリートでは, 曲げ耐力を算出す る際の応力ーひずみ曲線は 2 次曲線とされるが，高強度 繊維補強モルタルの応力とひずみとの関係はほぼ直線と なることがわかる．圧縮強度とヤング係数との関係を図 -8 に示寸. 式(1)は高強度コンクリートを用いた PC 構造 物の設計施工規準に示されている高強度コンクリートの ヤング係数の推定式である ${ }^{20)}$. 高強度繊維補強モルタル のヤング係数は，式(1)より小さく，式(1)を 0.85 倍した 計算値とほぼ一致している。高強度繊維補強モルタルは 粗骨材を使用していないことから，一般の高強度コンク リートに比べヤング係数が小さくなるものと考えられる.

$$
E_{c}=12.5 \cdot f_{c}^{\prime 1 / 4}
$$

ここに， $E_{c}$ はヤング係数 $\left(\mathrm{kN} / \mathrm{mm}^{2}\right) ， f_{c}^{\prime}$ はコンクリート の圧縮強度 $\left(\mathrm{N} / \mathrm{mm}^{2}\right)$ である。式(1)の適用範囲は 60〜 160N/mm² とされている.
表-9 強度性状

\begin{tabular}{|c|c|c|c|c|c|c|c|c|}
\hline \multirow[b]{2}{*}{ No. } & \multirow{2}{*}{\begin{tabular}{|c|} 
SF \\
混入率 \\
(vol.\%)
\end{tabular}} & \multicolumn{2}{|c|}{ 圧縮強度 } & \multicolumn{2}{|c|}{ ヤング係数 } & \multirow[b]{2}{*}{$\begin{array}{l}\text { 曲け強度 } \\
\left(\mathrm{N} / \mathrm{mm}^{2}\right)\end{array}$} & \multirow{2}{*}{$\begin{array}{c}\text { 割裂 } \\
\text { 引張強度 } \\
\left(\mathrm{N} / \mathrm{mm}^{2}\right) \\
\end{array}$} & \multirow[b]{2}{*}{ 備 考 } \\
\hline & & $\begin{array}{l}\text { 材齢 } 3 \text { 日 } \\
\left(\mathrm{N} / \mathrm{mm}^{2}\right)\end{array}$ & $\begin{array}{l}\text { 材齢 } 28 \\
\left(\mathrm{~N} / \mathrm{mm}^{2}\right)\end{array}$ & $\begin{array}{l}\text { 材齢3 } \\
\left(\mathrm{kN} / \mathrm{mm}^{2}\right)\end{array}$ & $\begin{array}{l}\text { 材齢2 } \\
\left(\mathrm{kN} / \mathrm{mm}^{2}\right)\end{array}$ & & & \\
\hline \multirow{6}{*}{$2-1$} & \multirow{6}{*}{0.0} & 161 & 166 & 37.3 & 38.0 & 10.0 & - & 事前試験 1-5 \\
\hline & & 165 & 163 & 39.0 & 36.3 & 9.5 & 7.3 & \\
\hline & & 168 & 170 & - & 39.4 & - & 9.9 & 世ん断載荷実験 \\
\hline & & 173 & 185 & - & 41.2 & 12.2 & 8.0 & 曲价載荷実験 \\
\hline & & 145 & - & 36.7 & - & - & - & クリーブ試験 \\
\hline & & 155 & - & 36.3 & - & - & - & 浸漬試験 \\
\hline \multirow{2}{*}{$2-2$} & \multirow{2}{*}{0.5} & 145 & - & 36.7 & - & - & - & クリーブ試験 \\
\hline & & 165 & 176 & - & 40.5 & 14.3 & 8.7 & 世ん断載荷実験 \\
\hline \multirow{6}{*}{$2-3$} & \multirow{6}{*}{1.0} & 153 & - & 36.9 & - & - & - & クリープ試験 \\
\hline & & 152 & 166 & 37.8 & 38.2 & 15.2 & - & \\
\hline & & 154 & 154 & - & 39.3 & 19.3 & 7.8 & 事前試験 1-6 \\
\hline & & 169 & 173 & 39.6 & 38.0 & 19.7 & 9.0 & \\
\hline & & 161 & 174 & - & 40.5 & 21.2 & 9.5 & せん断載荷実験 \\
\hline & & 170 & 185 & - & 41.5 & 17.0 & 8.8 & 曲げ載荷実験 \\
\hline $2-4$ & 2.0 & 153 & 164 & 37.6 & 38.0 & 24.9 & - & 事前試験 1-7 \\
\hline
\end{tabular}

注) 曲げ強度および割裂引張強度は材齢 3 日の結果

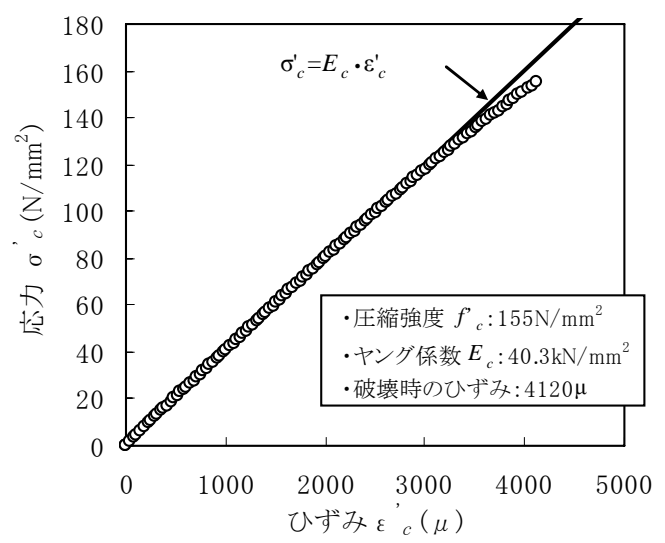

図-7 応力とひずみとの関係(一例)

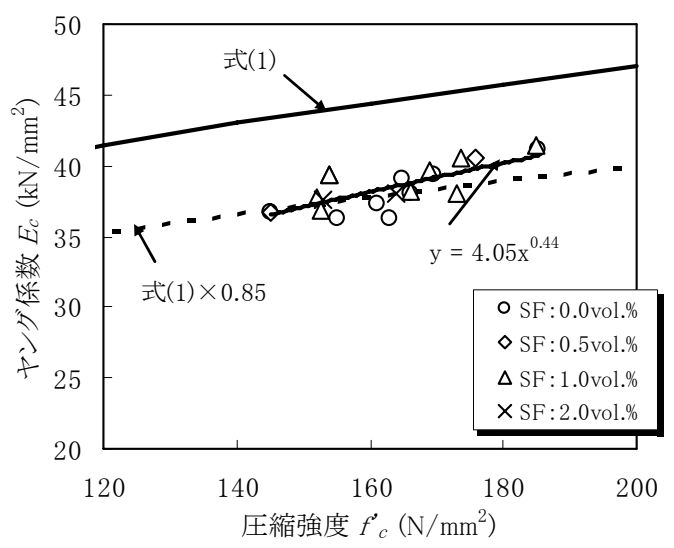

図-8＼cjkstart圧縮強度とヤング係数との関係

\section{c) 割裂引張強度}

高強度䋊維補強モルタルの圧縮強度と割裂引張強度と の関係を図-9 に示寸。なお，鋼繊維混入率 2.0vol.\%では 割裂引張強度の試験は実施していない. 図中の太線はコ ンクリート標準示方書に示されている引張強度の推定式 であり，式(2)により求めた值である ${ }^{21) .}$

$$
f_{t}=0.23 \cdot f_{c}^{\prime 2 / 3}
$$




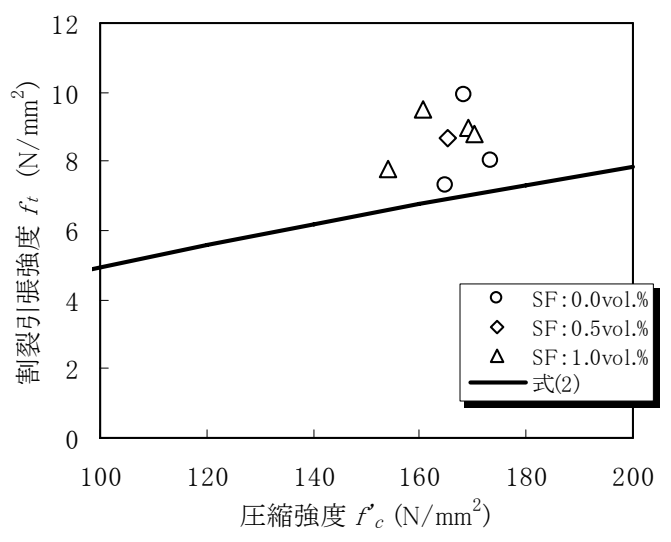

図-9＼cjkstart圧縮強度と割裂引張強度との関係

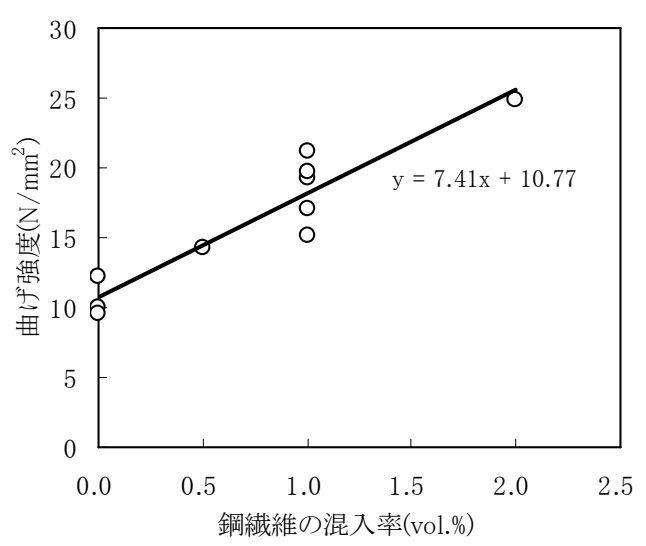

図-10 鋼繊維の混入率と曲げ強度との関係

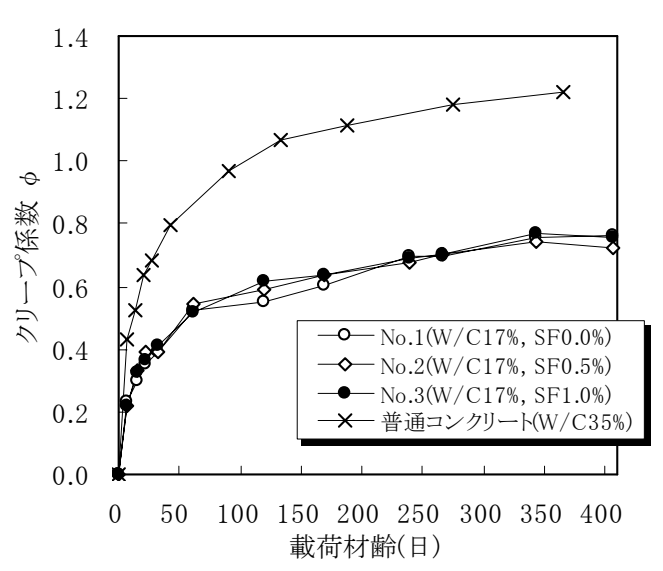

図-11 クリープ試験結果

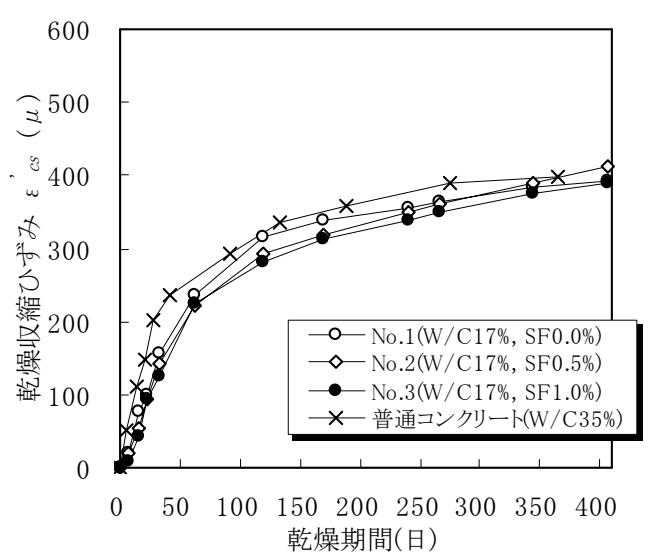

図-12 乾燥収縮試験結果

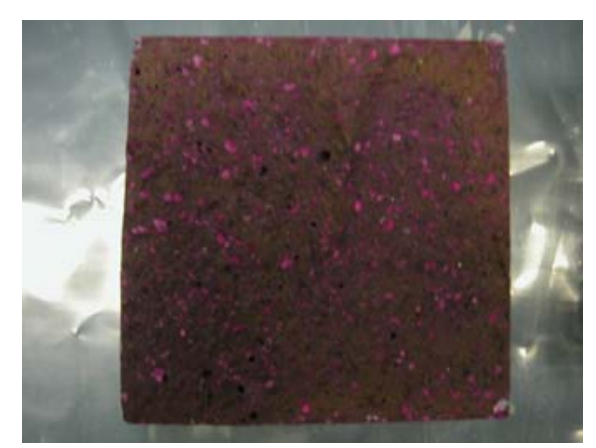

写真-7 フェノールフタレイン溶液の噴霧状況 
液の噴霧状況をそれぞれ，図-13 および写真-7 に示す.

高強度繊維補強モルタルは，促進中性化試験を 2 年実 施しても中性化深さは $0 \mathrm{~mm}$ であり，中性化に対し，十 分な耐久性を有していると考えられる.

\section{b) 凍結融解抵抗性}

凍結融解試験の結果を図-14 に示す。鋼䋊維の混入に より凍結融解抵抗性は向上するとされているため，今回 の試験は鋼䋊維を混入しないモルタルで行った ${ }^{17)}$. なお,

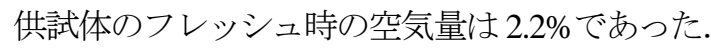

コンクリート標準示方書では，厳しい環境条件におい て高い耐久性が要求される場合は相対動弾性係数を95\% 以上に設定するのが望ましいとされている ${ }^{21)}$. 高強度繊 維補強モルタルは480 サイクルでも相対動弾性係数はほ とんど低下しおらず，95\%以上を満足している。また， 供試体にスケーリングやひび割れは認められなかった。 したがって, 高強度繊維補強モルタルは, 空気量が $2 \%$ 程度と少ないが十分な凍結融解抵抗性を有していると考 えられる。

\section{c) 見掛けの塩分拡散係数}

浸漬期間 26 ケ月後における供試体内部の塩化物イオ ン濃度の分布を図-15に，式(3)に準じて求めた見掛けの 塩分拡散係数を表-10 に示す ${ }^{24)}$.

$$
C(x, t)-C_{i}=C_{a 0}\left\{1-\operatorname{erf}\left(\frac{x}{2 \cdot \sqrt{D_{a p} \cdot t}}\right)\right\}
$$

ここに, $x$ は暴露面からの距離(cm), $t$ は浸漬期間(年), $C(x, t)$ は距離 $x(\mathrm{~cm})$, 浸漬期間 $t$ (年)における塩化物イオン 濃度の測定值 $\left(\mathrm{kg} / \mathrm{m}^{3}\right), C_{a 0}$ は浸漬試験によるコンクリート 表面の全塩化物イオン濃度 $\left(\mathrm{kg} / \mathrm{m}^{3}\right), C_{i}$ は初期に含有され るコンクリート中の全塩化物イオン濃度 $\left(\mathrm{kg} / \mathrm{m}^{3}\right), D_{a p}$ は 浸漬試験による見掛けの拡散係数, erf は䛠差関数である.

試験で求めた見掛けの塩分拡散係数 $0.0176 \mathrm{~cm}^{2} /$ 年を使 用し, 塩化物イオン濃度の経時変化を算出した結果を図 -16 に示す. 塩化物イオン濃度は, コンクリート標準示 方書 ${ }^{21)}$ に準拠して算出し, 算出条件は, 飛沫帯, かぶり $35 \mathrm{~mm}$ とした. 比較のため通常の PC 構造物に用いられ る普通コンクリートを使用した場合の塩化物イオン濃度 の計算結果も示した. なお，普通コンクリートの水セメ ント比は $36 \%{ }^{25)}$ と仮定し，見掛けの塩分拡散係数はコン クリート標準示方書の推定式 ${ }^{21)}$ よ $0.463 \mathrm{~cm}^{2}$ /年とした.

図-16より，普通コンクリートでは 5 年程度で鉄筋位 置におけるコンクリート中の塩化物イオン濃度が発錆限 界を超えるのに対し，高強度䋊維補強モルタルでは 100 年後においても $0.89 \mathrm{~kg} / \mathrm{m}^{3}$ であり，発錆限界 $1.2 \mathrm{~kg} / \mathrm{m}^{3}$ 以 下となっている。したがって，高強度繊維補強モルタル は，通常のコンクリートに比べ塩害に対する耐久性が高 く，かぶりが $35 \mathrm{~mm}$ あれば，飛沫帯においても塩害に対 して十分な耐久性を有すると考えられる. 一方，かぶり

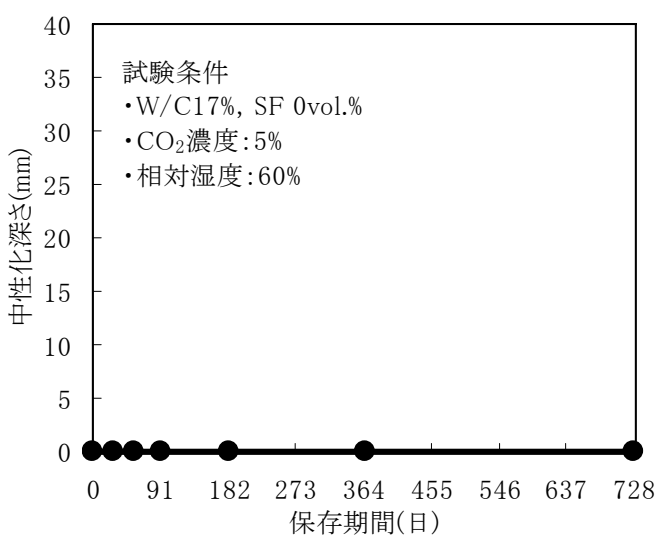

図-13 促進中性化試験の結果

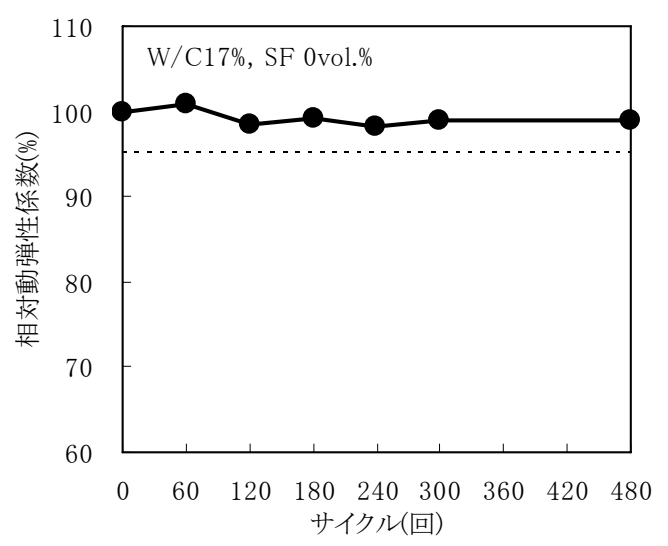

図-14 凍結融解試験の結果

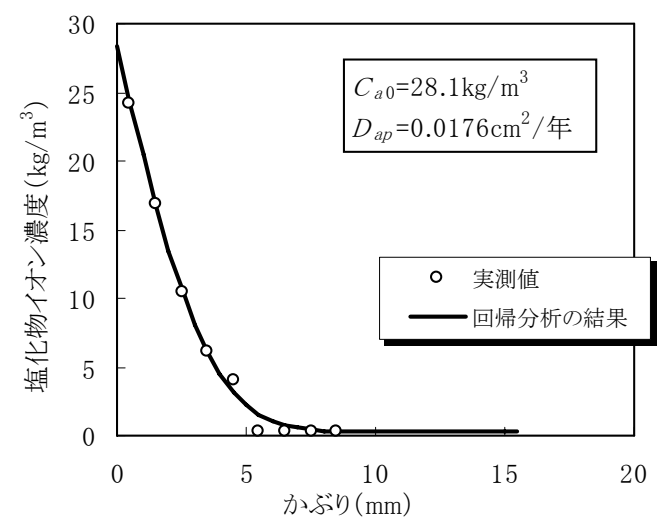

図-15 塩化物イオン濃度の分布

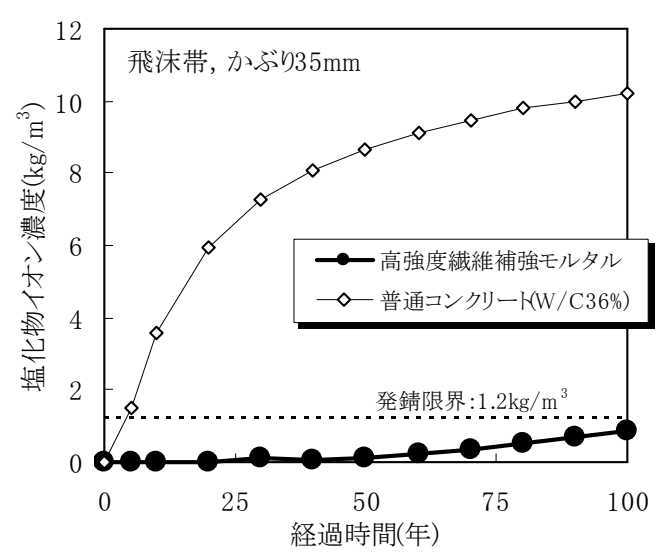

図-16 塩化物イオン濃度の計算値 
部分の鋼繊維の腐食に関しては，表面付近のみで内部へ はほとんど進行しないこと，および鋼繊維が犠牲陽極と して作用し内部の鉄筋が腐食しにくくなることが既往の 研究で報告されており ${ }^{26)}$ ，耐久性への影響はほとんどな いものと推察される.

\section{PC はりとしての構造特性一曲げ特性}

\section{(1) 実験方法}

高強度繊維補強モルタルを用いた PC はりの曲げモー メントに対する特性を確認するため PC はり供試体を製 作し，曲げ載荷実験を行った。

\section{a) 供試体および載荷方法}

供試体一般図および諸元をそれぞれ，図-17 および表 -11 に示す. 供試体は, 鋼繊維の有無をパラメーターと した 2 体とした. 断面寸法は，幅 $0.4 \mathrm{~m}$, 桁高 $0.4 \mathrm{~m}$, の I 形断面とし，支間は $12.0 \mathrm{~m}$ ，桁高支間比は $1 / 30$ とした. 供試体の製作はプレキャストセグメント工法で行い，3 つのプレキャストセグメントにポストテンション方式で プレストレスを導入して一体化した。 プレストレス導入 後はグラウトを行い，グラウトの材齢 7 日における圧縮 強度は 43.5N/mm² であった. 載荷は単純支持した供試体 の中央部に 2 点集中荷重を静的に作用させて行った. そ の際の純曲げ区間は $1 \mathrm{~m}$ とした. なお，ひび割れ間隔な どの曲げ特性への影響が懸念されたため, 供試体の純曲 げ区間部にはスターラップを配置しなかった。

\section{b) 使用材料}

曲げ載荷実験における使用材料，モルタルの配合およ び強度性状をそれぞれ，表-12，表-13 および表-14に示 す. なお，供試体には図-2 と同様の蒸気養生を行った。

\section{c) 非線形解析}

供試体の曲げ挙動を解析的に把握するため， 2 次元骨 組モデルによる非線形解析を実施した. 解析モデルおよ び解析に使用した要素をそれぞれ，図-18 および表-15 に示す.コンクリート，PC 鋼材および鉄筋はそれぞれ， 材料非線形性と幾何学的非線形性を考慮したはり要素お よび埋込み鉄筋要素でモデル化した．解析には汎用の有 限要素法プログラムである DIANA を使用し，解析モデ ルは対称性を考慮し，供試体全体の 1/2 とした. 高強度 繊維補強モルタル, PC 鋼材および鉄筋の材料非線形特性 は表-16および図-19 に示すとおりとした. 通常のコンク リートでは圧縮側の応力ーひずみ曲線は 2 次曲線とされ るのが一般的であるが, 図-7 のとおり高強度䋊維補強モ ルタルの応力ーひずみ曲線は破壊に至るまでほぼ直線と なることが確認されたことから，解析における応力一ひ ずみ曲線も破壊まで直線とした，なお，実際の PC はり 供試体はプレキャストセグメントで製作したが，本解析
表-10 見掛けの拡散係数(W/C=17\%)

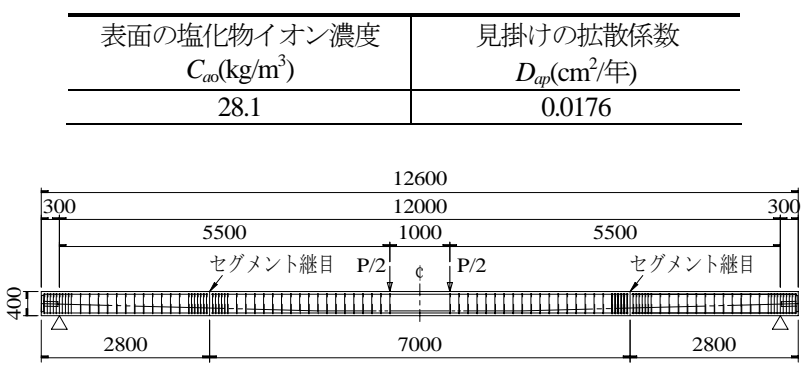

a) 側面図

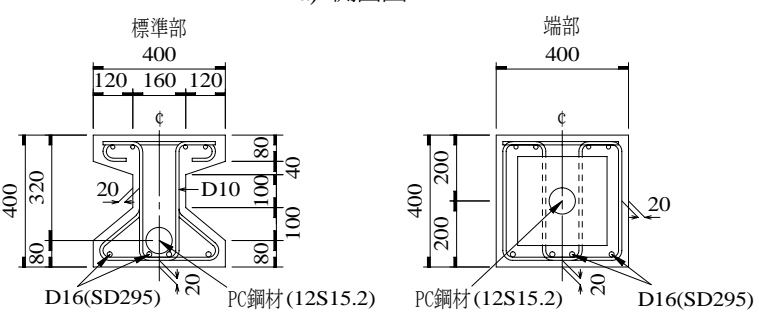

b) 断面図

(単位 : mm)

図-17 供試体一般図(曲げ載荷実験)

表-11 供試体の諸元

\begin{tabular}{|c|c|c|c|c|c|c|c|}
\hline \multirow[b]{2}{*}{ 供試体 } & \multirow[b]{2}{*}{$\begin{array}{l}\text { プレストレス } \\
\text { 導入方式 }\end{array}$} & \multirow{2}{*}{$\begin{array}{l}\text { 鋼繊維入率 } \\
\text { (vol.\%) }\end{array}$} & \multicolumn{2}{|c|}{ 断面寸法 } & \multirow[b]{2}{*}{$\begin{array}{c}\text { 支間 } \\
(\mathrm{m})\end{array}$} & \multirow[b]{2}{*}{$\begin{array}{c}\text { 桁高 } \\
\text { 支間比 }\end{array}$} & \multirow{2}{*}{$\begin{array}{c}\text { 有効 } \\
\text { 緊張力 } \\
(\mathrm{kN})\end{array}$} \\
\hline & & & $\begin{array}{l}\text { 幅 } \\
\text { (m) }\end{array}$ & $\begin{array}{l}\text { 高さ } \\
\text { (m) }\end{array}$ & & & \\
\hline $\mathrm{B}-1$ & ポストテンジ & 0.0 & 0,40 & 040 & 120 & $1 / 30$ & 1886 \\
\hline B-2 & 小ล下 & 1.0 & 0.40 & 0.40 & 12.0 & $1 / 30$ & 1000 \\
\hline
\end{tabular}

表-12 使用材料

\begin{tabular}{c|c|l}
\hline 材 料 & 記号 & \multicolumn{1}{|c}{ 仕 様 } \\
\hline セメント & C & 表-2 と同じ \\
\hline 細骨材 & S & 表-2, 砕砂-2 と同じ \\
\hline 鋼繊維 & SF & 表-2, 高張力鋼と同じ \\
\hline 高性能减水剂 & SP & 表-2 と同じ \\
\hline PC 鋼材 & - & SWPR7BL(12S15.2), 規格引張強度 $1850 \mathrm{~N} / \mathrm{mm}^{2}$ \\
\hline 鉄筋 & - & SD295A, 規格降伏点強度 $295 \mathrm{~N} / \mathrm{mm}^{2}$ \\
\hline
\end{tabular}

表-13 配合

\begin{tabular}{|c|c|c|c|c|c|c|c|c|}
\hline \multirow{2}{*}{ 供試体 } & \multirow{2}{*}{$\begin{array}{l}\mathrm{W} / \mathrm{C} \\
(\%)\end{array}$} & \multirow{2}{*}{$\begin{array}{l}\text { Air } \\
\text { (\%) }\end{array}$} & \multirow{2}{*}{$\begin{array}{c}\text { SF 量 } \\
\text { (vol.\%) }\end{array}$} & \multicolumn{4}{|c|}{ 単位量(kg/m3) } & \multirow{2}{*}{$\begin{array}{c}\mathrm{SP} / \mathrm{C} \\
\text { (\%) }\end{array}$} \\
\hline & & & & $\mathrm{W}$ & $\mathrm{C}$ & $\mathrm{S}$ & $\mathrm{SF}^{*}$ & \\
\hline B-1 & 17 & 2.0 & 0.0 & 210 & 1235 & 948 & 0 & 3.0 \\
\hline B-2 & 17 & 2.0 & 1.0 & 210 & 1235 & 948 & 79 & 3.0 \\
\hline
\end{tabular}

表-14 強度性状

\begin{tabular}{c|c|c|c|c|c}
\hline 供試体名 & 養生方法 & $\begin{array}{c}\text { 材齢 } \\
(\text { 日 })\end{array}$ & $\begin{array}{c}\text { 圧縮強度 } \\
\left(\mathrm{N} / \mathrm{mm}^{2}\right)\end{array}$ & $\begin{array}{c}\text { ヤング係数 } \\
\left(\mathrm{kN} / \mathrm{mm}^{2}\right)\end{array}$ & $\begin{array}{c}\text { 割裂引張強度 } \\
\left(\mathrm{N} / \mathrm{mm}^{2}\right)\end{array}$ \\
\hline $\mathrm{B}-1$ & 蒸気養生 & 28 & 185 & 41.2 & $8.0^{*}$ \\
\hline $\mathrm{B}-2$ & 蒸気養生 & 28 & 185 & 41.5 & $8.8^{*}$ \\
\hline
\end{tabular}

* 割裂引張強度は材齢 3 日の結果

表-15 解析に使用した要素

\begin{tabular}{c|c|c}
\hline 部 材 & 材料特性 & 要素モデル \\
\hline 高強度繊維補強モルタルの部材 & 非線形 & はり要素 \\
\hline PC 鋼材, 鉄筋 & 非線形 & 埋め込み鉄筋棒要素 \\
\hline
\end{tabular}

においてはプレキャストセグメントの継目の影響は考慮 していない. 


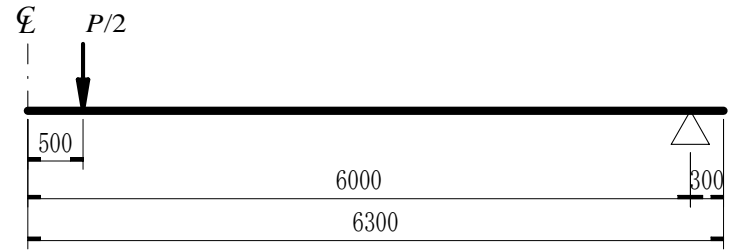

図-18 解析モデル

(単位 : mm)

\section{（2） 実験結果および考察}

\section{a) 荷重と変位との関係}

曲げ載荷実験における荷重と変位との関係，ひび割れ 発生荷重と曲げ破壊荷重をそれぞれ，図-20および表-17 に示寸．ここでの変位は供試体の支間中央部における変 位である．曲げひび割れ発生荷重の計算値は，はり下縁 の曲げ引張応力度が引張強度 $\left(8 \mathrm{~N} / \mathrm{mm}^{2}\right)$ に達する荷重と し，曲げ破壊荷重の計算值は作用曲げモーメントが破壊 抵抗曲げモーメントに達する荷重とした。 なお，破壊抵 抗曲げモーメントの計算では非線形解析の場合と同様, モルタルの応力ーひずみ曲線を直線と仮定し，終局ひず みを $4458 \mu\left(=f_{c}^{\prime}{ }_{c} / E_{c}\right)$ とした。

図-20 より, B-1 および B-2 供試体の曲げひび割れ発生 荷重および曲げ破壊荷重はともに計算值を上回っており, 高強度䋊維補強モルタルを用いた PC はりは, 通常の PC 構造物と同様の方法で曲げひび割れ発生モーメントおよ び曲げ耐力を評価できることがわかる． B-1 と B-2 とを 比較すると，鋼繊維を 1.0vol.\%混入した B-2 の方がひび 割れ発生荷重で 2 割程度，曲げ破壊荷重で 1 割程度上回 っており，鋼繊維はひび割れ発生モーメントと曲げ耐力 の向上に寄与していると考えられる. また，B-1 の荷重 と変位との関係は非線形解析の結果とよく一致しており, 今回設定した表-16 および図-19 の材料非線形特性は鋼 繊維を混入しない場合に関してはおおむ称妥当なもので あると考えられる．ただし，今回の解析では PC 鋼材の 引張強度に規格值を使用しており, 実際の引張強度がこ れより若干高いことを考慮すると，曲げ耐力の実験值も 解析值より若干高くなるべきと考えられる。高くならな かった理由としては，モルタルの圧縮強度のばらつき， グラウトの損傷による PC 鋼材の付着切れなどが挙げら れる。一方，鋼䋊維を混入した場合の材料非線形特性に 関しては, モルタルの引張軟化特性を把握した上で, 新 たに検討寸る必要がある。

\section{b) 破壊状況}

供試体の破壊状況を写真-8 および写真-9 に示す．B-1 および B-2 の破壊形態はともに PC 鋼材が降伏した後に 圧縮縁のモルタルが圧壊する曲げ引張破壊であったが， 破壊後の状況には大きな差が認められた。鋼繊維を混入 していない B-1 は破壊時に純曲げ区間部のモルタルが飛 散し, 断面全体が消失しているが, 鋼繊維を混入した B-2 は載荷点付近が圧壊しているのみであり, 純曲げ区間の
表-16 材料非線形特性

\begin{tabular}{|c|c|c|c|c|c|}
\hline 材 料 & 項 目 & 記号 & 単位 & 特性値 & 備 考 \\
\hline \multirow{5}{*}{$\begin{array}{l}\text { 高強度 } \\
\text { 繊維補強 } \\
\text { モルタルル }\end{array}$} & 圧縮強度 & $f_{c}^{\prime}$ & $\mathrm{N} / \mathrm{mm}^{2}$ & 185 & \\
\hline & 引張強度 & $\overline{f_{t}}$ & $\mathrm{~N} / \mathrm{mm}^{2}$ & 8.0 & \\
\hline & ヤング係数 & $E_{c}$ & $\mathrm{kN} / \mathrm{mm}^{2}$ & 41.5 & \\
\hline & 終局ひずみ(圧縮) & $\varepsilon_{c u}^{\prime}$ & $\mu$ & 4458 & $f_{c}^{\prime} / E_{c}$ \\
\hline & 終局ひずみ(引張) & $\varepsilon_{t}$ & $\mu$ & 193 & $f_{t} / E_{c}$ \\
\hline \multirow[t]{4}{*}{$\overline{\mathrm{PC} \text { 鋼材 }}$} & 引镸強度 & $f_{p u}$ & $\mathrm{~N} / \mathrm{mm}^{2}$ & 1850 & \\
\hline & 降伏強度 & $0.84 f_{p u}$ & $\mathrm{~N} / \mathrm{mm}^{2}$ & 1554 & \\
\hline & 降伏強度 & $0.93 f_{p u}$ & $\mathrm{~N} / \mathrm{mm}^{2}$ & 1721 & \\
\hline & ヤング係数 & $E_{p}$ & $\mathrm{kN} / \mathrm{mm}^{2}$ & 200 & \\
\hline \multirow[t]{2}{*}{ 鉄 筋 } & 降伏点強度 & $f_{s y}$ & $\mathrm{~N} / \mathrm{mm}^{2}$ & 295 & \\
\hline & ヤング係数 & $E_{s}$ & $\mathrm{kN} / \mathrm{mm}^{2}$ & 200 & \\
\hline
\end{tabular}

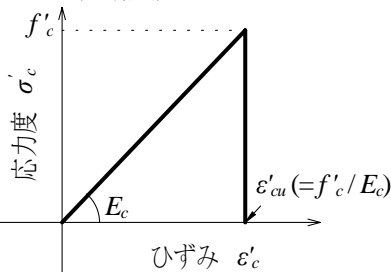

a) モルタル(圧縮側)

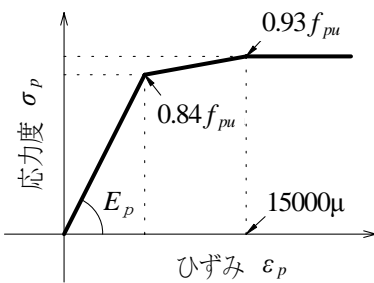

c) $\mathrm{PC}$ 鋼材

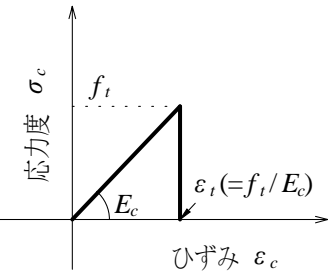

b) モルタル(引張側)

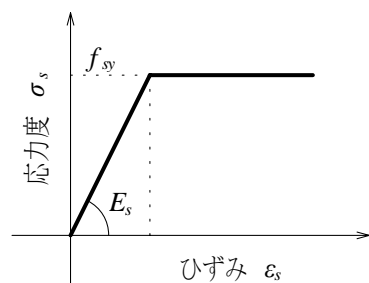

d) 鉄筋
図-19 非線形解析における応力一ひずみ曲線

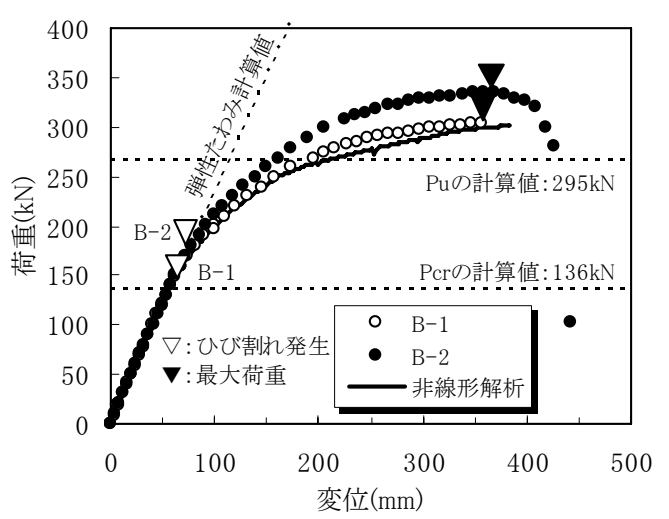

図-20 荷重と変位との関係

表-17 ひび割れ発生荷重と曲げ破壊荷重

\begin{tabular}{c|r|r|r|r|r|r}
\hline \multirow{2}{*}{ 供試体 } & \multicolumn{2}{|c|}{ 曲げひび割れ発生荷重 } & \multicolumn{3}{|c|}{ 曲け破壊荷重 } \\
\cline { 2 - 7 } & $\begin{array}{c}\text { 実験值 } \\
(\mathrm{kN})\end{array}$ & $\begin{array}{c}\text { 計算值 } \\
(\mathrm{kN})\end{array}$ & 比 & $\begin{array}{c}\text { 実験值 } \\
(\mathrm{kN})\end{array}$ & $\begin{array}{c}\text { 計算值 } \\
(\mathrm{kN})\end{array}$ & 比 \\
\hline B-1 & 140 & 136 & 1.03 & 304 & 295 & 1.03 \\
\hline B-2 & 170 & 136 & 1.25 & 335 & 295 & 1.14 \\
\hline
\end{tabular}

大部分は残っている．鋼繊維を混入することで，破壊後 の断面の状態が大きく改善されることが確認された.

c) 終局ひずみ

荷重と供試体上縁のひずみ $\varepsilon_{c}^{\prime}$ の関係を図-21 に示す. 
なお，ここでの上縁ひずみは支間中央部のものである.

B-1およびB-2の曲げ破壊時の終局ひずみはそれぞれ， $4571 \mu$ および $4311 \mu$ であり，通常の設計で用いるコンク リートの終局ひずみ $3500 \mu^{21)}$ をきく上回っている.ま た，終局ひずみの実験值は，モルタルの圧縮強度をヤン グ係数で除した值 $4450 \mu\left(\fallingdotseq 185 \mathrm{~N} / \mathrm{mm}^{2} / 41.5 \mathrm{kN} / \mathrm{mm}^{2}\right)$ と ほぼ一致している. B-1 と B-2 の終局ひずみを比較する とほとんど同程度であり，スターラップなど横方向を拘 束する鉄筋がない場合は，鋼䋊維の混入が終局ひずみに 及ぼす影響はほとんどないことがわかる。

\section{d) PC 鋼材のひずみ}

荷重と PC 鋼材ひずみ $\varepsilon_{p}$ との関係を図-22 に示す。こ こでの PC 鋼材ひずみは支間中央部のもので，供試体上 縁の圧縮ひずみと最下段の鉄筋のひずみから平面保持の 仮定に準じて算出した值である.

図-22 より, B-1 およびB-2 の PC 鋼材のひずみはとも に, 1 次降伏ひず夕の $7770 \mu\left(=0.84 \cdot f_{p u} / E_{p}\right)$ 付近から急激 に大きくなっており, 最終的には $15000 \mu$ を超えている.

したがって，B-1 および B-2 はともに曲げ破壊時におい て PC 鋼材が降伏しており，供試体の破壊形態は曲げ弓 張破壊であることが確認された. B-1 と B-2 とを同じ荷 重で比較すると, B-2 の方が PC 鋼材のひずみが小さくな っており，これは鋼䋊維が引張力を負担したことによる と考えられる. また, 非線形解析の結果は B-1 の PC 鋼 材ひずみとほぼ一致しており，非線形解析を行う際に設 定した表-16 および図-19 の材料非線形特性は鋼繊維を 混入しない場合に関してはおおむ水妥当であると考えら れる. 鋼繊維を混入した場合の材料非線形特性に関して は今後，モルタルの引張軟化特性などを考慮し，新たに 検討する必要がある.

\section{e) 応カーひずみ曲線の検討}

曲げ耐力算出時の忘力ーひずみ曲線の種類と曲げ耐力 の計算結果を表-18 に示す. 高強度䋊維補強モルタルの 圧縮応力とひずみの関係は破壊に至るまでほぼ直線であ り，コンクリート標準示方書のように応力ーひずみ曲線 を 2 次曲線 ${ }^{21)}$ とするのは不合理と考えられる. そこで, モルタルの応力ーひずみ曲線を直線またはバイリニアと した場合の曲げ耐力を検討した．ケース 1 は応力ーひず み曲線を直線とした場合であり，ケース 2 およびケース 3 はそれぞれ，UFCの設計施工指針(案) ${ }^{5}$ および高強度コ ンクリートを用いた PC 構造物の設計施工規準 ${ }^{20)}$ に示さ れている応力ーひずみ曲線である. なお, 曲げ而力算出 の際の圧縮強度は高強度䋊維補強モルタルで想定してい る設計基準強度 $120 \mathrm{~N} / \mathrm{mm}^{2}$ とし，ヤング係数は材料試験 の值を参考として $38 \mathrm{kN} / \mathrm{mm}^{2}$ とした.

表-18より，各ケースの曲げ耐力の計算值は同程度で あり，今回検討した応力ーひずみ曲線では曲げ而力の計 算值にほとんど差はないことがわかる.ケース 1 とケー

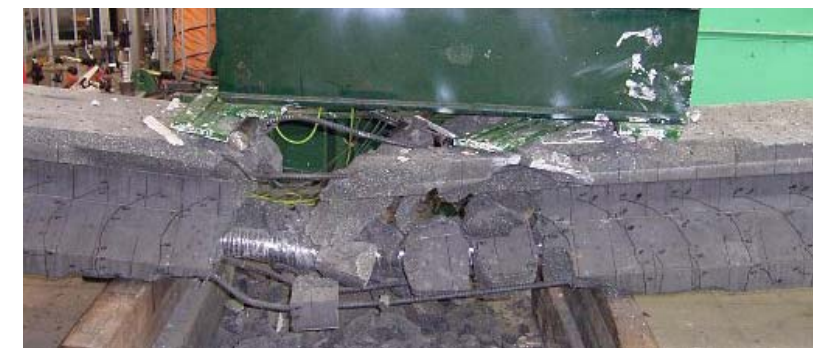

写真-8 破壊状況 (B-1 : 鋼繊維なし)

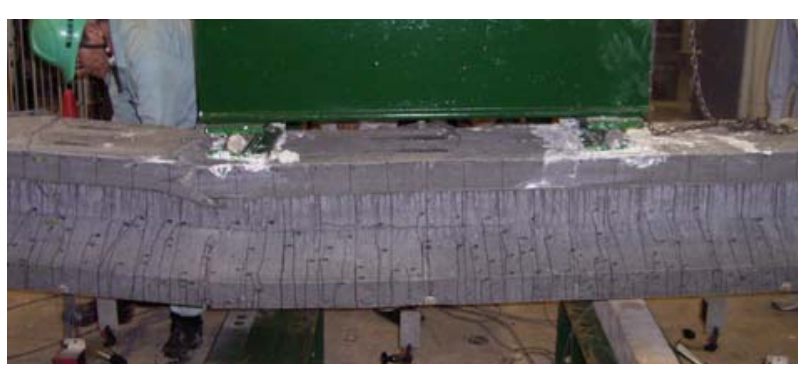

写真-9 破壊状況 (B-2 : 鋼繊維あり)

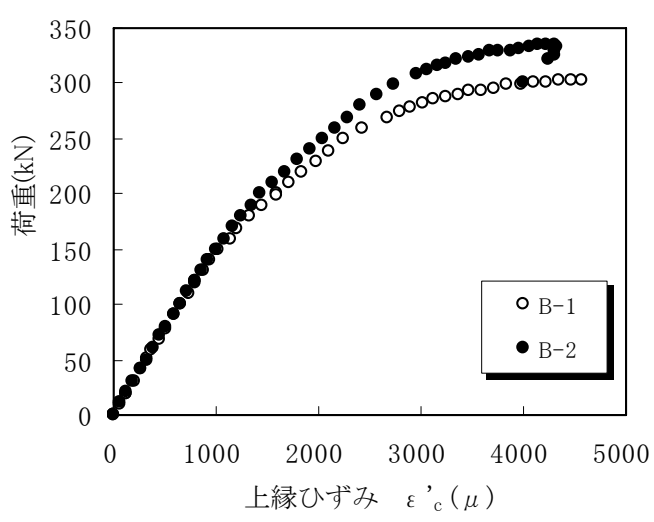

図-21荷重と上縁ひずみとの関係

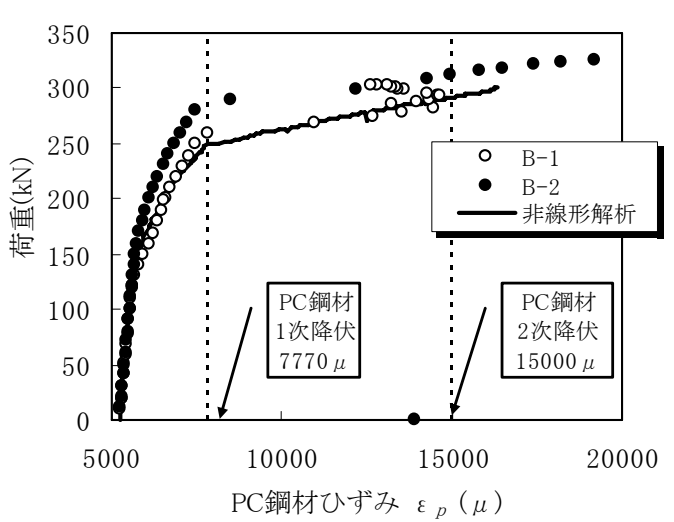

図-22 荷重と PC 鋼材ひずみとの関係

ス 2 とを比較すると，ケース 2 は最大応力度を $0.85 f_{c k}^{\prime}$ としているものの終局ひずみを $3500 \mu$ としていることか ら曲げ耐力を若干大きく評価している．一方，終局ひず みに圧縮強度をヤング係数で除した值を使用したケース 1 とケース 3 とを比較すると, ケース 3 では最大応力度 を $0.76 f_{c k}^{\prime}$ としていることから $2 \%$ 程度安全側の評価にな っている. しかし，今回検討したケースでは終局ひずみ 
表-18 応力ーひずみ曲線の種類と曲げ耐力の計算結果

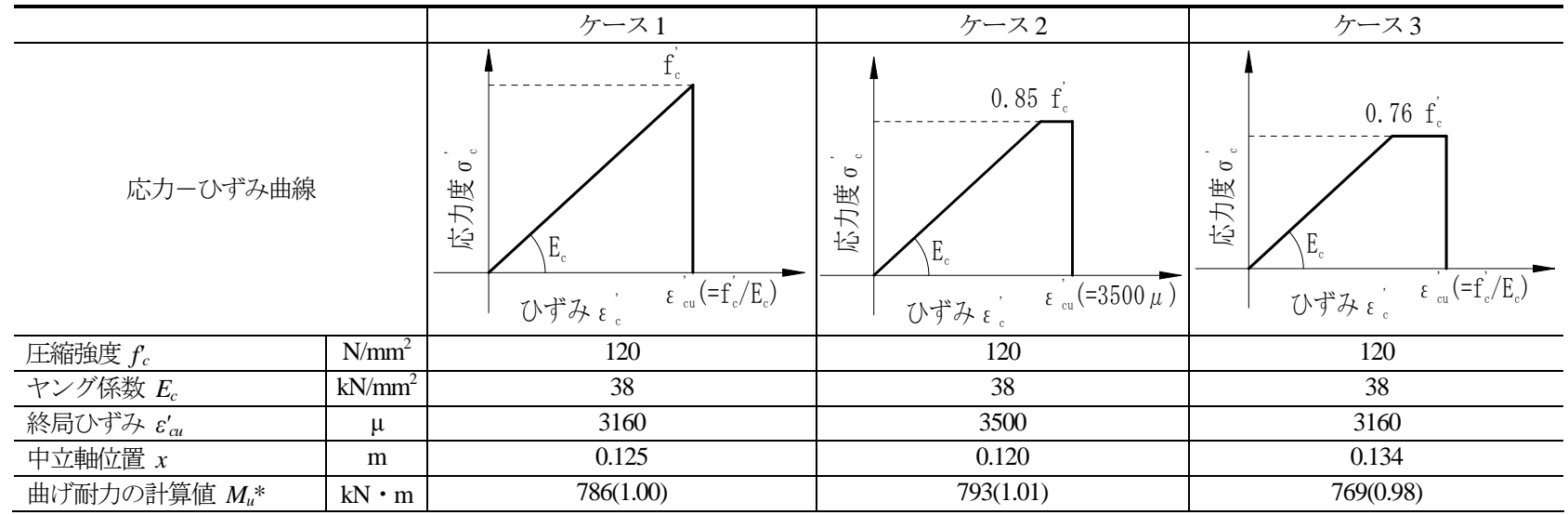

*( )はケース 1 に対する比率

や圧縮側のストレスブロックにより曲げ而力に大きな相 違は認められなかった。

\section{f) 曲げひび割れ幅}

鉄筋のひずみ $\varepsilon_{s e}$ と曲げひび割れ幅 $w$ との関係を図-23 に示す. 鉄筋のひずみ $\varepsilon_{s e}$ は支間中央部の引張鉄筋に貼り 付けたひずみゲージにより計測した值であり，ひび割れ 発生時を 0 とした増加ひずみの実測值である. 曲げひび 割れ幅 $w$ は支間中央部に最も近い位置に発生したひび割 れの幅を $\pi$ ゲージ(標点 $10 \mathrm{~cm})$ によ計測したものであ る. 曲げひび割れ幅 $w$ の計算值は，コンクリート標準示

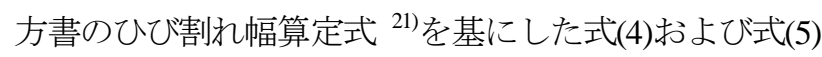
により算出した．鋼繊維を混入すると，ひび割れの分散 効果が高まり，ひび割れ間隔が小さくなるとの報告があ ることから ${ }^{27)}$, 式(5)では鋼䋊維の混入によるひび割れ間

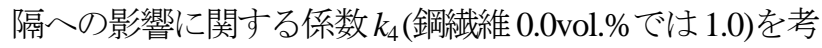
慮した. なお，鋼繊維の混入により鉄筋応力度の増加量 $\sigma_{s e}$ が小さくなることも考えられるが 27), 式(4)および式(5) において鋼䋊維が $\sigma_{s e}$ に及ぼす影響は考慮していない.

$$
\begin{gathered}
w=l_{\max } \cdot\left[\frac{\sigma_{s e}}{E_{s}}+\varepsilon_{c s d}^{\prime}\right] \\
l_{\max }=1.1 \cdot k_{1} \cdot k_{2} \cdot k_{3} \cdot k_{4} \cdot\left\{4 c+0.7\left(c_{s}-\phi\right)\right\}
\end{gathered}
$$

ここに, $l_{\max }$ は式(5)で算出される最大ひび割れ間隔, $\sigma_{s e}$ は鉄筋応力度の増加量 $\left(=\varepsilon_{s e} \times E_{s}\right), E_{s}$ は鋼材のヤング係数, $\varepsilon_{c s d}^{\prime}$ は収縮およびクリープ等によるひずみ(本実験では 0), $k_{1}$ は鋼材の表面形状がひび割れ幅に及ぼす影響を表す係 数(異形鉄筋は 1.0), $k_{2}$ はコンクリートの品質がひび割れ 幅に及ぼす影響[= 15 / $\left.\left(f_{c}^{\prime}+20\right)+0.7\right], f_{c}{ }^{\prime}$ はコンクリートの 圧縮強度 $\left(\mathrm{N} / \mathrm{mm}^{2}\right), k_{3}$ は引張鋼材の段数の影響を表す係数 [= 5(n+2) / (7n+8)], $n$ は引張鋼材の段数，cははかぶり， $c_{s}$ は鋼材中心間隔， $\phi$ は鋼材径を表す.

図-23 より，B-1 の曲げひび割れ幅は， $k_{4}$ を 1.0 として 式(4)および式(5)により算出した計算值とほぼ一致して おり，鋼繊維を混入しない場合は，コンクリート標準示

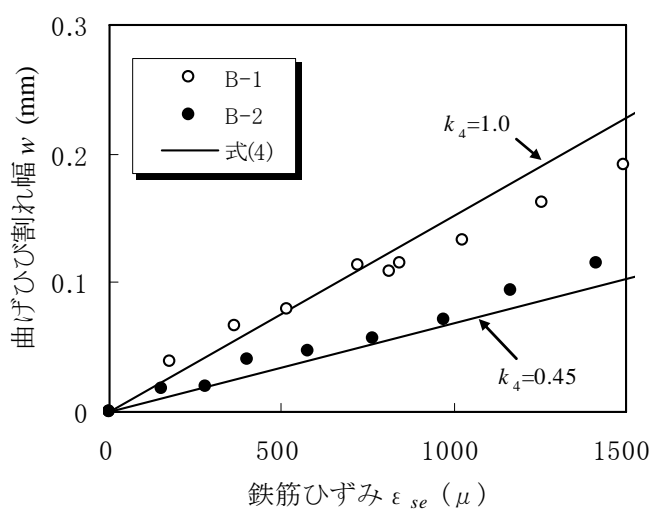

図-23鉄筋ひずみとひび割れ幅との関係

表-19 純曲げ区間のひび割れ間隔

\begin{tabular}{c|c|c|c|c|c}
\hline & $\begin{array}{c}\text { 純曲げ } \\
\text { 区間の } \\
\text { ひび割れ } \\
\text { 本数 }\end{array}$ & $\begin{array}{c}\text { 平均 } \\
\text { ひび割れ } \\
\text { 間隔 } \\
(\mathrm{mm})\end{array}$ & $\begin{array}{c}\text { 最大 } \\
\text { ひび割れれ } \\
\text { 間隔 } \\
(\mathrm{mm})\end{array}$ & $\begin{array}{c}\text { 計測位置 } \\
\text { の平均 } \\
\text { ひび割れ } \\
\text { 間隔 }\end{array}$ & $\begin{array}{c}\text { 計算值 } \\
(\mathrm{mm})\end{array}$ \\
\hline B-1 & 9 & 125 & 175 & 100 & 152 \\
\hline B-2 & 23 & 45 & 75 & 45 & 152 \\
\hline 比 & - & 0.36 & 0.42 & 0.45 & - \\
\hline
\end{tabular}

方書のひび割れ幅算定式でひび割れ幅を評価できると考 えられる.一方, 鋼繊維を混入した B-2 のひび割れ幅は, ひび割れ発生後の初期の段階から B-1 に比べ小さいこと がわかる.これは鋼繊維を混入した場合は図-24 に示す とおり，ひび割れの分散性が向上し，ひび割れ間隔が小 さくなったこと，および鋼繊維の混入により鉄筋応力度 が低減したことなどによると考えられる。

純曲げ区間のひび割れ間隔を表-19 に示す. B-2 と B-1 のひび割れ間隔の比率は，平均ひび割れ間隔で 0.36 , 最 大ひび割れ間隔で 0.42, 計測位置のひび割れ間隔で 0.45 となっている．計測位置の平均ひび割れ間隔の比率 0.45 を $k_{4}$ とし, 式(4)および式(5)により B-2 のひび割れ幅を計 算すると, 実験值とよく一致し，ひび割れ間隔を考慮す ることで高強度繊維補強モルタルのひび割れ幅が適切に 評価されたと考えられる. なお，式(4), 式(5)では鋼䋊維 
B-1

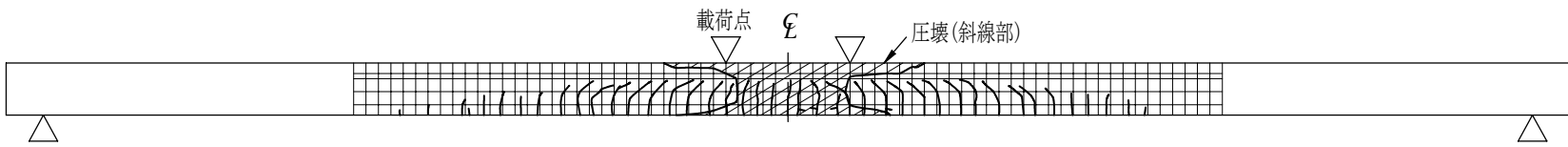

B-2

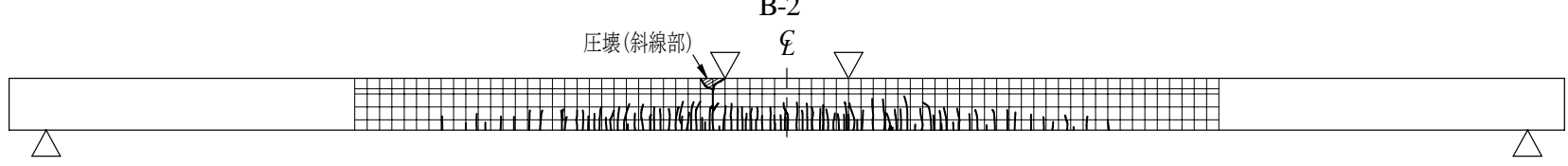

a) 全体
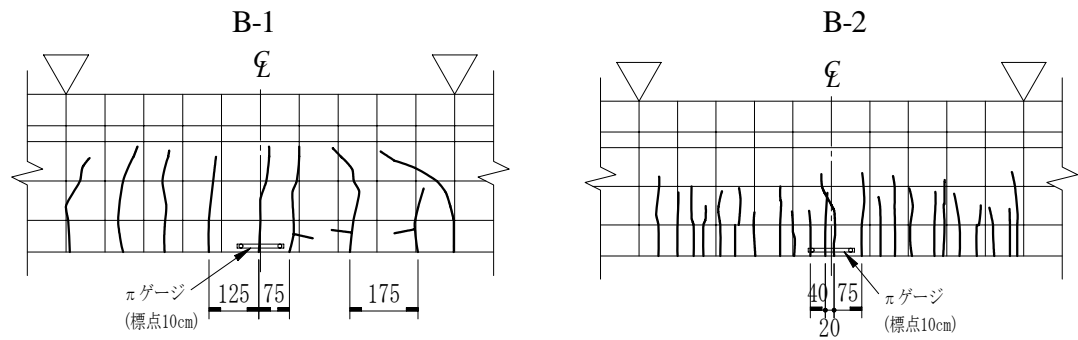

b) 純曲げ区間部の拡大

図-24 ひび割れ発生状況

(単位 : mm)

の混入による鉄筋応力度の低減を考慮していないため $k_{4}$ にはその影響が含まれている可能性がある。また，今回 の実験では $k_{4}$ を定量的に評価するには至らなかった. $k_{4}$ には鋼繊維の混入率, 長さ, 直径, アスペクト比, モル タルの引張軟化特性などが影響すると考えられ，今後こ れらの影響を考慮し， $k_{4}$ を定量的に評価する方法を検討 する必要がある.

\section{PC 部材としての構造特性一せん断挙動}

\section{（1）実験方法}

高強度䋊維補強モルタルを用いた PC はりのせん断力 に対する特性を確認するため, PC はり供試体および鉄筋 コンクリート(以降， RC)はり供試体を製作し，せん断載 荷実験を行った.

\section{a) 供試体および載荷方法}

供試体一般図および諸元をそれぞれ，図-25 および表 -20 に示す。供試体はプレストレスの有無, 鋼䋊維の有 無, せん断補強鉄筋の有無をパラメータとした 8 体とし た. 断面は，幅 $0.10 \mathrm{~m}$ ，高さ $0.40 \mathrm{~m}$ の矩形とし，支間は $2.4 \mathrm{~m}$ とした. 曲げ破壊を先行させないため引張鋼材には 公称直径 $36 \mathrm{~mm}$ の PC 鋼棒を 2 段に配置した. RC はり供 試体に関しては上段, 下段ともに異形PC鋼棒としたが, PC はり供試体に関しては, プレストレスを導入するため 上段の PC 鋼棒のみを丸鋼とし，プレストレス導入後， グラウトを行った．PC 鋼棒の有効緊張力の計算值は $155 \mathrm{kN}$ であり，PC はり供試体には上縁で-1.9N/ $\mathrm{mm}^{2}$ ，下 縁で $9.7 \mathrm{~N} / \mathrm{mm}^{2}$, 平均で $3.9 \mathrm{~N} / \mathrm{mm}^{2}$ のプレストレスが導入

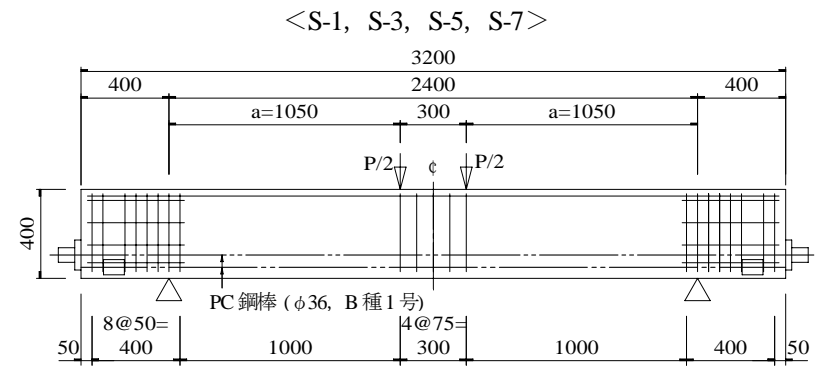

$<$ S-2, S-4, S-6, S-8 $>$

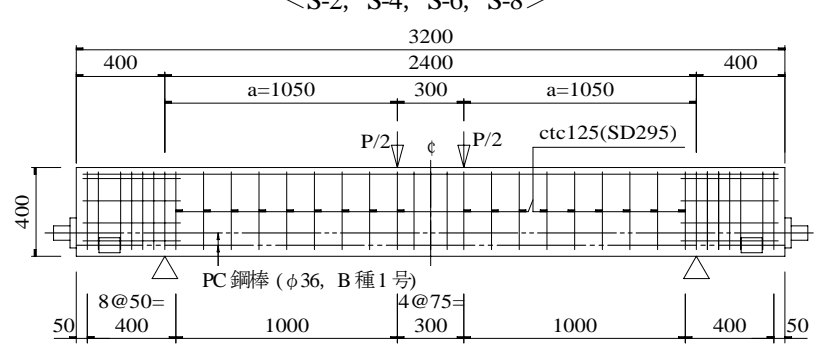

a) 側面図

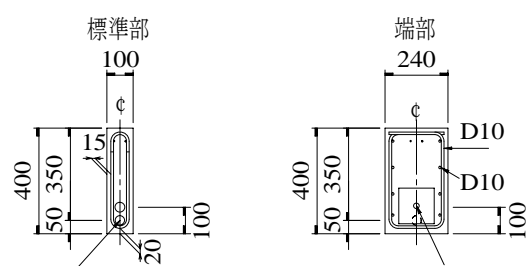

$\mathrm{PC}$ 鋼棒 ( $\phi 36, \mathrm{~B}$ 種 1 号)

PC 鋼棒 ( $\phi 36, \mathrm{~B}$ 種 1 号)

b) 断面図

(単位 : mm)

図-25 供試体一般図

された(マイナスは引張応力度). 載荷は単純支持した供 試体の中央部に 2 点集中荷重を静的に作用させて行った. その際の純曲げ区間は $0.30 \mathrm{~m}$ とした。 
表-20 供試体の諸元

\begin{tabular}{c|c|c|c|c|c|c}
\hline $\begin{array}{c}\text { 供試体 } \\
\text { 番号 }\end{array}$ & $\begin{array}{c}\text { 部材 } \\
\text { 種類 }\end{array}$ & $\begin{array}{c}\text { SF 混入量 } \\
(\text { vol.\%) }\end{array}$ & $\begin{array}{c}\text { 有効高 } \\
d(\mathrm{~m})\end{array}$ & a/d & $\begin{array}{c}\text { せん断 } \\
\text { 補強筋 }\end{array}$ & $\begin{array}{c}\text { 有効緊張力 } \\
P_{e}(\mathrm{kN})\end{array}$ \\
\hline S-1 & RC & 0.0 & 0.35 & 3.0 & 無 & 0 \\
\hline S-2 & RC & 0.0 & 0.35 & 3.0 & D10ctc125 & 0 \\
\hline S-3 & RC & 0.5 & 0.35 & 3.0 & 無 & 0 \\
\hline S-4 & RC & 0.5 & 0.35 & 3.0 & D6ctc125 & 0 \\
\hline S-5 & PC & 0.0 & 0.35 & 3.0 & 無 & 155 \\
\hline S-6 & PC & 0.0 & 0.35 & 3.0 & D10ctc125 & 155 \\
\hline S-7 & PC & 0.5 & 0.35 & 3.0 & 無 & 155 \\
\hline S-8 & PC & 0.5 & 0.35 & 3.0 & D6ctc125 & 155 \\
\hline
\end{tabular}

表-22 配合

\begin{tabular}{c|c|c|c|c|c|c|c|c}
\hline \multirow{2}{*}{ 供試体 } & W/C & Air & SF 量 & \multicolumn{4}{|c|}{ 単位量 $\left(\mathrm{kg}^{2} / \mathrm{m}^{3}\right)$} & \multicolumn{1}{c}{$\mathrm{SP} / \mathrm{C}$} \\
\cline { 5 - 8 } & $(\%)$ & $(\%)$ & $($ vol.\%) & W & C & S & SF & (\%) \\
\hline S-1,S-2,S-5,S-6 & 17 & 2.0 & 0.0 & 210 & 1235 & 948 & 0 & 3.0 \\
\hline S-3,S-4,S-7,S-8 & 17 & 2.0 & 0.5 & 210 & 1235 & 948 & 40 & 3.0 \\
\hline
\end{tabular}

\section{b) 使用材料}

せん断破壊実験における使用材料，配合および強度性 状をそれぞれ，表-21，表-22 および表-23 に示す. なお， 本実験においても，はり供試体には図-2に示す蒸気養生 を行った。

\section{(2) 実験結果および考察}

\section{a) 荷重と変位との関係}

荷重と変位との関係を図-26に示す。 RC はり供試体, PC はり供試体はともに, スターラップを使用した供試体 (S-2，S-4，S-6，S-8)の方が使用していない供試体(S-1, S-3, S-5, S-7)に比べ, せん断耐力が大きい傾向にある.

\section{b) 斜めひび割れ発生荷重およびせん断破壊荷重}

斜めひび割れ発生荷重およびせん断破壊荷重を表-24 に示す。ここでの斜めひび割れ発生荷重は，せん断支間 部の斜めひび割れが断面図心位置を超えた時点の荷重と した．斜めひび割れ発生荷重は，鋼䋊維を混入しない供 試体が $100 〜 120 \mathrm{kN}$ ，鋼䋊維を混入した供試体が $200 \mathrm{kN}$ 〜 $220 \mathrm{kN}$ であり，鋼繊維を混入した供試体の方が大きい 傾向にある. 一方， 世ん断破壊荷重は，鋼繊維の混入の ほか，プレストレスの導入およびせん断補強筋の配置に よっても大きくなっている.

\section{c) 破壊状況}

供試体のひび割れ発生状況およひ破壊状況を図-27に 示す. なお, 鋼䋊維を混入していない RC の供試体(S-1, S-2)に関しては点線で示すように載荷前に収縮によると 考えられるひび割れが発生したが，それ以外の鋼繊維を 混入した供試体やプレストレスを導入した供試体にはひ び割れは認められなかった。なお，このひび割れは供試 体製作から 1 週間以内の比較的短期間で発生したことか ら，乾燥収縮よりも自己収縮の影響で発生したものと考 えられる。

表-24に示したとおり供試体の破壊形態は S-1 を除き， すべてせん断圧縮破壊であった，すなわち，斜めひび割
表-21 使用材料

\begin{tabular}{|c|c|c|}
\hline 材 料 & 記号 & 仕 様 \\
\hline セメント & $\mathrm{C}$ & 表-2 と同じ \\
\hline 細骨材 & $S$ & 表-2, 砕砂-2 と同じ \\
\hline 鋼繊維 & SF & 表-2, 高張力鋼と同じ \\
\hline 高性能減水剂 & SP & 表-2 と同じ \\
\hline PC 鋼材 & - & $\begin{array}{l}\text { PC 鋼棒 } \phi 36 \mathrm{~mm}(\mathrm{SBPD} 930 / 1080, \mathrm{SBPR} 930 / 1080 *) \\
\text { 降伏ひずみ } 4650 \mu\left(=930 \mathrm{~N} / \mathrm{mm}^{2} / 200 \mathrm{kN} / \mathrm{mm}^{2}\right)\end{array}$ \\
\hline 鉄筋 & - & SD295A，規格降伏点強度 $295 \mathrm{~N} / \mathrm{mm}^{2}$ \\
\hline
\end{tabular}

表-23 強度性状

\begin{tabular}{c|c|c|c|c|c}
\hline 供試体名 & 養生方法 & $\begin{array}{c}\text { 材齢 } \\
(日)\end{array}$ & $\begin{array}{c}\text { 圧縮強度 } \\
\left(\mathrm{N} / \mathrm{mm}^{2}\right)\end{array}$ & $\begin{array}{c}\text { ヤング係数 } \\
\left(\mathrm{kN} / \mathrm{mm}^{2}\right)\end{array}$ & $\begin{array}{c}\text { 割裂引張強度 } \\
\left(\mathrm{N} / \mathrm{mm}^{2}\right)\end{array}$ \\
\hline S-1,S-2,S-5,S-6 & 蒸気養生 & 28 & 170 & 39.4 & $9.9^{*}$ \\
\hline S-3,S-4,S-7,S-8 & 蒸気養生 & 28 & 176 & 40.5 & $8.7^{*}$ \\
\hline * 割裂引張強度は材齢3 3 の結果
\end{tabular}

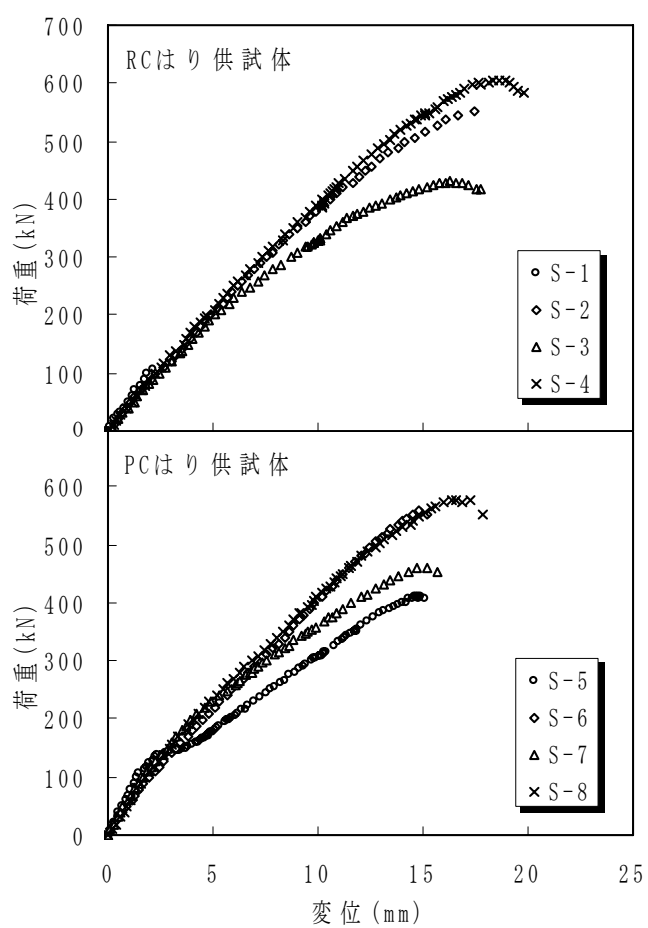

図-26 せん断載荷実験の荷重と変位との関係

表-24 斜めひび割れ発生荷重およびせん断破壊荷重

\begin{tabular}{|c|c|c|c|c|c|}
\hline \multirow[b]{2}{*}{ 供試体 } & \multirow{2}{*}{\begin{tabular}{|c|} 
斜め \\
ひひ搳狆 \\
発生荷重 \\
$(\mathrm{kN})$
\end{tabular}} & \multirow[b]{2}{*}{$\begin{array}{c}\text { せん断 } \\
\text { 破壞何重 } \\
(\mathrm{kN})\end{array}$} & \multicolumn{2}{|c|}{ 破壊時のひずみ* } & \multirow[b]{2}{*}{ 破壊形態 } \\
\hline & & & $\begin{array}{c}\text { はり上縁 } \\
\varepsilon_{c}^{\prime}(\mu) \\
\end{array}$ & $\begin{array}{c}\text { 下段 PC 鋼材 } \\
\varepsilon_{p}(\mu) \\
\end{array}$ & \\
\hline S-1 & 100 & 108 & 539 & 311 & 斜引張破壊 \\
\hline $\mathrm{S}-2$ & 110 & 554 & 2943 & 2127 & せん断圧縮破壊 \\
\hline S-3 & 210 & 432 & 2738 & 1767 & せん断圧縮破壊 \\
\hline S-4 & 200 & 608 & 3537 & 2332 & せん断圧縮破壊 \\
\hline S-5 & 120 & 412 & 3135 & 1865 & せん断圧縮破壊 \\
\hline S-6 & 120 & 560 & 3477 & 2257 & せん断圧縮破壊 \\
\hline S-7 & 220 & 462 & 2913 & 1862 & せん断圧縮破壊 \\
\hline S-8 & 220 & 580 & 2616 & 2273 & せん断圧縮破壊 \\
\hline
\end{tabular}

*支間中央部の実測值

れが発生した後もしばらく載荷荷重が増加し，引張鋼材 (降伏ひずみ $4650 \mu$ )が降伏する前に載荷点付近が圧壊し 
S-1(RC，SF0.0\%，スターラップ無)

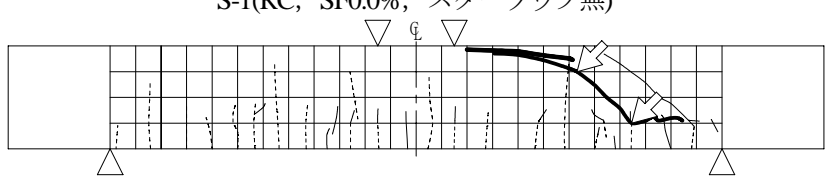

S-3(RC，SF0.5\%，スターラップ無)

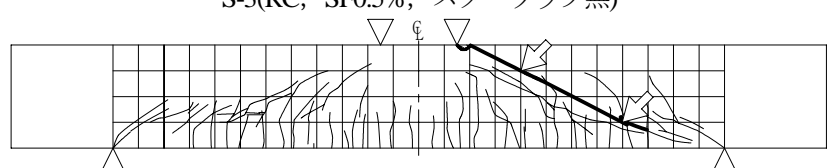

S-5(PC，SF0.0\%，スターラップ無)

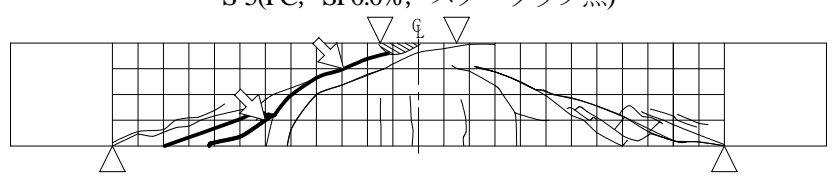

S-7(PC，SF0.5\%，スターラップ無)

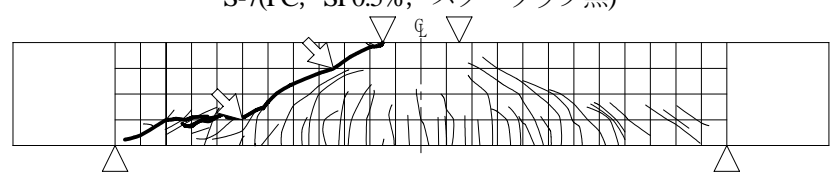

S-2(RC，SF0.0\%，スターラップ有)

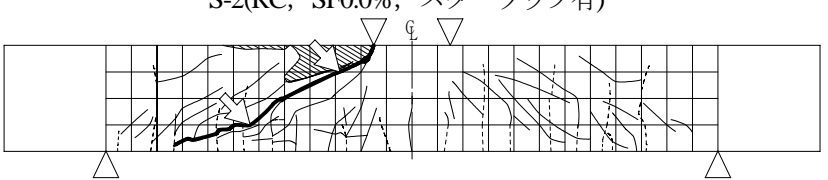

S-4(RC, SF0.5\%，スターラップ有)

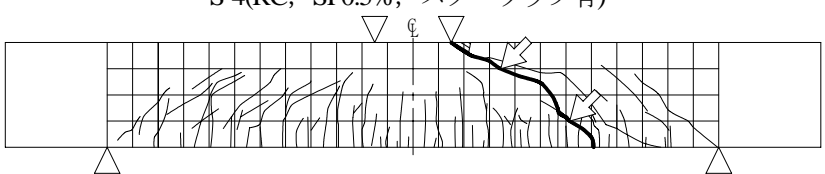

S-6(PC，SF0.0\%，スターラップ有)

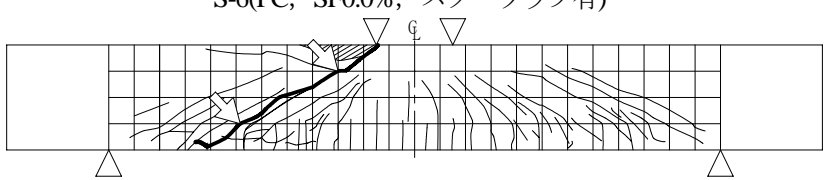

S-8(PC，SF0.5\%，スターラップ有)

図-27ひび割れ状況およひ破壊状況

表-25 モルタルが負担するせん断力の実験值と計算值の比較

\begin{tabular}{|c|c|c|c|c|c|c|c|c|c|c|c|c|c|c|c|c|}
\hline \multirow[b]{2}{*}{ 供試体 } & \multirow{2}{*}{$\begin{array}{c}\text { 斜め } \\
\text { ひび割れ } \\
\text { 発生荷重 } \\
(\mathrm{kN})\end{array}$} & \multirow{2}{*}{$\begin{array}{c}V_{c} の \\
\text { 実験值 } \\
V_{c \text { cexp }} \\
(\mathrm{kN})\end{array}$} & \multicolumn{3}{|c|}{$V_{c}$ の計算值 } & \multirow[b]{2}{*}{$\begin{array}{c}f_{c}^{\prime} \\
\left(\mathrm{N} / \mathrm{mm}^{2}\right)\end{array}$} & \multirow[b]{2}{*}{$\begin{array}{c}f_{v} \\
\left(\mathrm{~N} / \mathrm{mm}^{2}\right)\end{array}$} & \multirow[b]{2}{*}{$\beta_{d}$} & \multirow[b]{2}{*}{$\beta_{p}$} & \multirow[b]{2}{*}{$\beta_{n}$} & \multirow[b]{2}{*}{$\beta_{f}$} & \multirow[b]{2}{*}{$\begin{array}{c}b_{w} \\
(\mathrm{~m})\end{array}$} & \multirow[b]{2}{*}{$\begin{array}{c}d \\
\text { (m) }\end{array}$} & \multirow[b]{2}{*}{$\begin{array}{c}p \\
(\%)\end{array}$} & \multirow[b]{2}{*}{$\begin{array}{c}M_{u} \\
(\mathrm{kN} \cdot \mathrm{m})\end{array}$} & \multirow[b]{2}{*}{$\begin{array}{c}M_{0} \\
(\mathrm{kN} \cdot \mathrm{m})\end{array}$} \\
\hline & & & $\begin{array}{l}\text { 式(6) } \\
V_{\text {c.cal }} \\
(\mathrm{kN})\end{array}$ & $\begin{array}{l}\text { 式(7) } \\
V_{\text {c.cal }} \\
(\mathrm{kN})\end{array}$ & $\begin{array}{c}\text { 式(8) } \\
V_{\text {c.cal }} \\
(\mathrm{kN})\end{array}$ & & & & & & & & & & & \\
\hline S-1 & 100 & 50 & 49.1 & 82.1 & 49.1 & 170 & 0.72 & 1.30 & 1.5 & 1.0 & 1.000 & 0.1 & 0.35 & 5.82 & 452.3 & 0 \\
\hline S-2 & 110 & 55 & 49.1 & 82.1 & 49.1 & 170 & 0.7 & 1.30 & 1.5 & 1.0 & 1.000 & 0.1 & 0.35 & 5.82 & 452.3 & 0 \\
\hline S-3 & 210 & 105 & 49.1 & 83.6 & 92.7 & 176 & 0.72 & 1.30 & 1.5 & 1.0 & 1.886 & 0.1 & 0.35 & 5.82 & 452.3 & 0 \\
\hline S-4 & 200 & 100 & 49.1 & 83.6 & 92.7 & 176 & 0.72 & 1.30 & 1.5 & 1.0 & 1.886 & 0.1 & 0.35 & 5.82 & $\begin{array}{l}452.3 \\
\end{array}$ & 0 \\
\hline S-5 & 120 & 60 & 54.1 & 82.1 & 54.1 & 170 & 0.72 & 1.30 & 1.5 & 1.1 & 1.000 & 0.1 & 0.35 & 5.82 & 466.7 & 23.6 \\
\hline S-6 & 120 & 60 & 54.1 & 82.1 & 54.1 & 170 & 0.72 & 1.30 & 1.5 & 1.1 & 1.000 & 0.1 & 0.35 & 5.82 & 466.7 & 23.6 \\
\hline S-7 & 220 & 110 & 54.1 & 83.6 & 102.1 & 176 & 0.72 & 1.30 & 1.5 & 1.1 & 1.886 & 0.1 & 0.35 & 5.82 & 466.7 & 23.6 \\
\hline S-8 & 220 & 110 & 54.1 & $\begin{array}{l}83.6 \\
\end{array}$ & 102.1 & 176 & 0.72 & 1.30 & 1.5 & 1.1 & 1.886 & 0.1 & 0.35 & 5.82 & 466.7 & 23.6 \\
\hline
\end{tabular}

て破壊に至った。せん断補強鉄筋と鋼絨維がなくトラス 機構が成立しない S-1 の破壊形態は斜引張破壊であった.

\section{d) 高強度繊維補強モルタルが負担するせん断力 $V_{c}$}

高強度繊維補強モルタルが負担するせん断力 $V_{c}$ の実 験值 $V_{\text {c.exp }}$ と計算值 $V_{\text {c.cal }}$ の比較, 実験值と式(6)による計 算值との比較, および実験值と式(7)による計算值との比 較をそれぞれ，表-25，図-28 および図-29に示す。ここ で，実験值 $V_{\text {c.exp }}$ は供試体の斜めひび割れ発生時(斜めひ び割れ発生荷重)における作用せん断力とし, 計算值 $V_{\text {c.cal }}$ は式(6)および式(7)により求めた。.式(6)および式(7)はと もに，せん断補強鋼材を用いない棒部材のせん断而力の 算定式であり，式(6)はコンクリート標準示方書 ${ }^{21)}$, 式(7) は超高強度繊維補強コンクリートの設計施工指針案(以 降, UFC 指針) ${ }^{5}$ に準拠した式である. なお，式(6)による 計算值の算出においては $f_{v c}, \beta_{d}$ および $\beta_{p}$ はコンクリー 卜標準示方書に定められている上限值を上回ったため, それぞれ上限值の $0.72 \mathrm{~N} / \mathrm{mm}^{2} ， 1.5$ および 1.5 とした ${ }^{21)}$.

$$
\begin{gathered}
V_{c . c a l}=\beta_{d} \cdot \beta_{p} \cdot \beta_{n} \cdot f_{v c} \cdot b_{w} \cdot d \\
f_{v c}=0.20 \sqrt[3]{f_{c}^{\prime}}
\end{gathered}
$$

$$
\begin{gathered}
\beta_{d}=\sqrt[4]{1000 / d} \\
\beta_{p}=\sqrt[3]{100 \cdot p} \\
\beta_{n}=1+2 \cdot M_{0} / M_{u} \\
V_{c . c a l}=0.18 \cdot \sqrt{f_{c}^{\prime}} \cdot b_{w} \cdot d \\
V_{c . c a l}=\beta_{d} \cdot \beta_{p} \cdot \beta_{n} \cdot \beta_{f} \cdot f_{v c} \cdot b_{w} \cdot d
\end{gathered}
$$

ここに， $M_{u}$ は軸方向力を考慮しない純曲げ而力, $M_{0}$ はデコンプレッションモーメント， $b_{w}$ は腹部の幅 $(\mathrm{mm})$, $d$ は有効高さ $(\mathrm{mm}), p$ は引張鉄筋比 $\left[A_{s} /\left(b_{w} \cdot d\right)\right], A_{s}$ は 引張側鋼材の断面積 $\left(\mathrm{mm}^{2}\right), f^{\prime}{ }_{c}$ はモルタルの圧縮強度 $\left(\mathrm{N} / \mathrm{mm}^{2}\right), \beta_{f}$ は鋼䋊維の影響(鋼䋊維なしは 1.0)である.

図-28 より，式(6)による計算值は，鋼絨維を混入して いない供試体に関しては実験值とはほぼ一致しているが, 鋼繊維を混入した供試体に関しては実験值が計算值の 2 倍程度となっている. コンクリート標準示方書に準拠し た式(6)は, 鋼繊維が混入されていない場合には $V_{c}$ をほぼ 適切に評価しているが，鋼繊維が混入された場合には過 小評価になるといえる.ここで，鋼繊維を混入した供試 体と無混入の供試体とでは, 鋼䋊維の有無以外は同条件 
であることから, 実験值 $V_{\text {cexp }}$ の差は鋼䋊維のみの影響と 考えられる. そこで，鋼䋊維を混入した供試体と混入し ていない供試体の回帰式の比 1.886(=2.0567／1.0905)を 鋼䋊維が $V_{c}$ に及ぼす影響 $\beta_{f}$ とし，式(6)を式(8)のとおり 修正した. 式(8)による計算值は鋼繊維を混入した供試体 に関しても実測值とほぼ対応しており， $\beta_{f}$ を考慮するこ とで鋼繊維を混入した場合の $V_{c}$ を適切に評価できると 考えられる.ただし， $\beta_{f}$ は鋼繊維の長さ，直径，アスペ クト比, 引張強度および混入率などの影響を受けると考 えられ, データ数も少ないため, これらの影響を考慮し た $\beta_{f}$ の定量化については今後の課題となる.

一方, 図-29より, 鋼䋊維を混入していない供試体の 実験值は式(7)による計算值を下回っているが, 鋼繊維を 混入した供試体の実験值は計算值の 1.3 倍程度となって いる. UFC 指針に準拠した式(7)は, 鋼䋊維を混入してい ない場合は危険側の評価となるが，鋼䋊維を混入した場 合は式(6)よりも適切に $V_{c}$ を評価できるといえる.

\section{e) せん断耐力 $V$}

せん断而讨力の実験值 $V_{\text {exp }}$ と計算值 $V_{\text {cal }}$ との比較を図-30 および表-26 に示寸. せん断耐力の実験值 $V_{\text {exp }}$ はせん断 破壊時の作用せん断力とし, 計算值 $V_{\text {cal }}$ はコンクリート 標準示方書に準拠し, 式(9)および式(10)により算出した. なお，モルタルが負担するせん断力の計算值 $V_{\text {c.cal }}$ は $\beta_{f}$ を考慮した式(8)により算出した.

$$
\begin{gathered}
V_{\text {cal }}=V_{\text {c.cal }}+V_{\text {s.cal }} \\
V_{\text {s.cal }}=f_{w y} \cdot A_{w} \cdot z / s \\
V_{\text {s.cal }}=f_{w y} \cdot A_{w} \cdot z / \tan \beta_{u} / s
\end{gathered}
$$

ここに， $V_{\text {c.cal }}$ は式(8)による計算值， $V_{\text {s.cal }}$ はせん断補強 鉄筋が負担するせん断力の計算值, $f_{w y}$ はせん断補強鉄筋 の降伏点強度, $A_{w}$ は区間 $s$ におけるせん断補強鉄筋の全 断面積, $\mathrm{z}$ はアーム長で一般に $d / 1.15, s$ はせん断補強鉄 筋のピッチである.

図-30より, せん断而的力の実験值 $V_{\text {c.exp }}$ は, 鋼絨維を混 入した供試体では計算值の 2.1 倍程度, 鋼䋊維を混入し ていない供試体では計算值の 1.9 倍程度となっており, コンクリート標準示方書に準拠し, 式(9)および式(10)に より算出したせん断耐力は安全側の評価になることがわ かる. 式(10)では，せん断補強鉄筋が負担するせん断力 が安全側の評価となるよう斜めひび割れの角度 $\beta_{u}$ を $45^{\circ}$ としているが，図-27 に示したとおり，せん断破壊 の原因となった斜めひび割れの角度は $45^{\circ}$ よりも小さ くなっている. 斜めひび割れの角度が小さくなると, 斜 めひび割れと交差するせん断補強鉄筋が増加し, せん断 補強鉄筋が負担寸るせん断力が大きくなるため, 式(11) により斜めひび割れの角度 $\beta_{u}$ を考慮することとした.な お, 斜めひび割れの角度 $\beta_{u}$ は, 図心軸(上縁から 200mm) と斜めひび割れのな寸角度の実測值とし, 図-27 の斜め

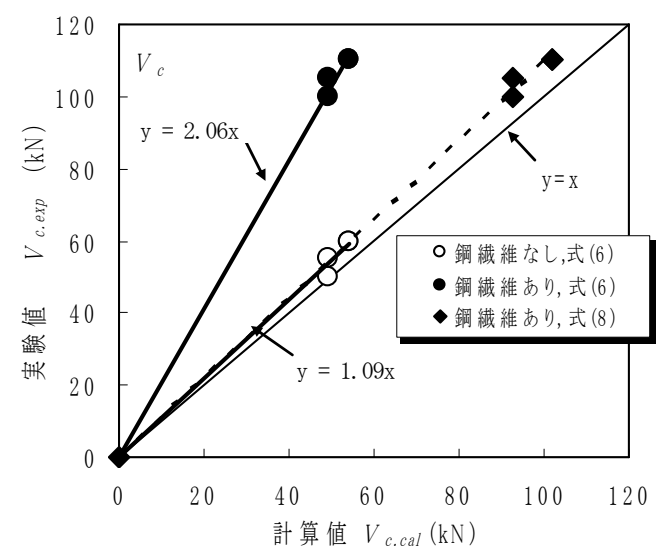

図-28 $V_{c}$ の実験值と式(6)による計算値との比較

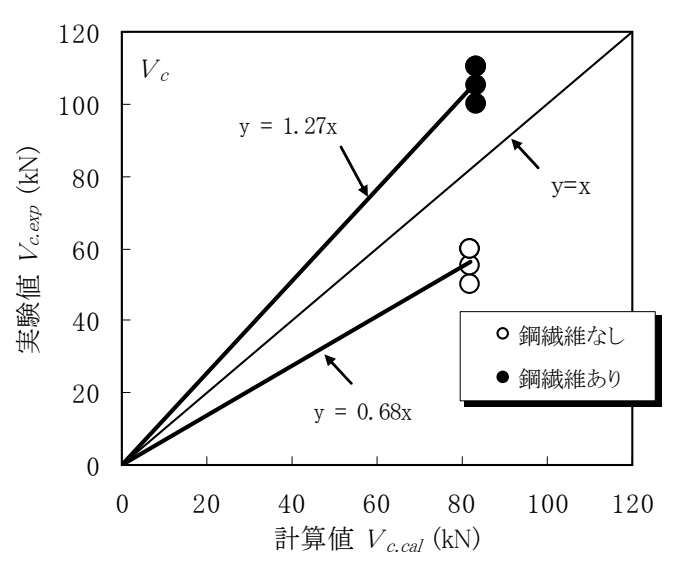

図-29 $V_{c}$ の実験值と式(7)による計算值との比較

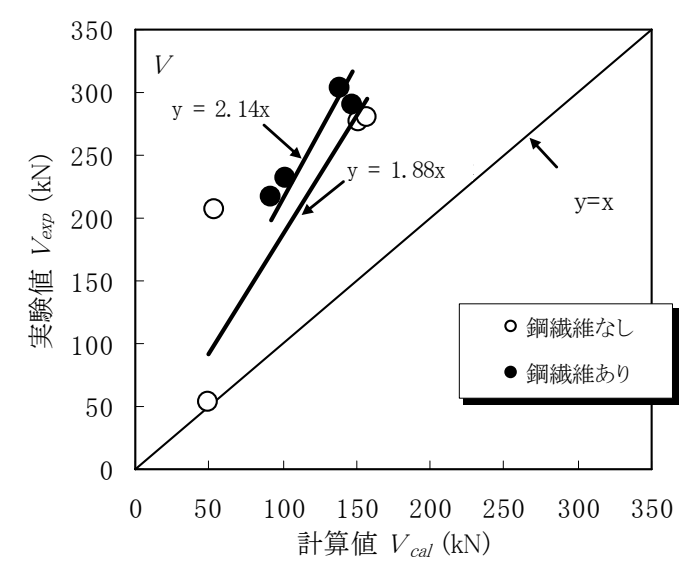

図-30 せん断耐力の実験值と計算值との比較

ひび割れ上の二つの矢印(図心軸から上下 $100 \mathrm{~mm}$ 離れた グリッド線と斜めひび割れの交点)を結ぶ直線と図心軸 のなす角度として求めた.

斜めひび割れの角度を考慮し，式(9)および式(11)によ り算出したせん断耐力の計算值と実験值との比較を図 -31 および表-26に示寸.鋼繊維を混入していない供試体 に関しては, 実験值が計算值の 1.2 倍程度となっており, 斜めひび割れの角度 $\beta_{u}$ を考慮することでせん断耐力の 計算值の精度が向上したといえる，一方，鋼繊維を混入 した供試体に関しては, 実験值が計算值の 1.9 倍程度と 
表-26 せん断耐力の実験值と計算值との比較

\begin{tabular}{|c|c|c|c|c|c|c|c|c|c|c|c|}
\hline \multirow[b]{2}{*}{ 供試体 } & \multirow{2}{*}{$\begin{array}{c}\text { せん断 } \\
\text { 破壞荷重 } \\
(\mathrm{kN})\end{array}$} & \multirow{2}{*}{$\begin{array}{l}\text { 実験值 } \\
V_{\text {exp }} \\
(\mathrm{kN})\end{array}$} & \multicolumn{2}{|c|}{ せん断耐力の計算値 $V_{c a l}$} & \multirow{2}{*}{$\begin{array}{l}\text { 式(8) } \\
V_{\text {c.cal }} \\
(\mathrm{kN})\end{array}$} & \multirow{2}{*}{$\begin{array}{l}\text { 式(10) } \\
V_{\text {s.al }} \\
(\mathrm{kN}) \\
\end{array}$} & \multirow{2}{*}{$\begin{array}{c}\text { 式(11) } \\
V_{\text {sacal }} \\
(\mathrm{kN}) \\
\end{array}$} & \multirow[b]{2}{*}{$\begin{array}{c}f_{s y} \\
\left(\mathrm{~N} / \mathrm{mm}^{2}\right)\end{array}$} & \multirow[b]{2}{*}{$\begin{array}{c}A_{w} \\
\left(\mathrm{~mm}^{2}\right)\end{array}$} & \multirow[b]{2}{*}{$\begin{array}{c}s \\
(\mathrm{~m})\end{array}$} & \multirow[b]{2}{*}{$\begin{array}{l}\beta_{u_{u}}{ }^{1} \\
\left({ }^{\circ}\right)\end{array}$} \\
\hline & & & $\begin{array}{c}\text { 式(8)+式(10) } \\
(\mathrm{kN})\end{array}$ & $\begin{array}{c}\text { 式(8)+式(11) } \\
(\mathrm{kN})\end{array}$ & & & & & & & \\
\hline S-1 & 108 & 54 & 49 & 49 & 49.1 & 0.0 & 0.0 & 295 & 0.0 & 0.125 & 43.0 \\
\hline S-2 & 554 & 277 & 152 & 231 & 49.1 & 103.1 & 181.5 & 295 & 71.3 & 0.125 & 29.6 \\
\hline S-3 & 432 & 216 & 93 & 93 & 92.7 & 0.0 & 0.0 & 295 & 0.0 & 0.125 & 26.7 \\
\hline S-4 & 608 & 304 & 139 & 155 & 92.7 & 45.8 & 62.1 & 295 & 31.7 & 0.125 & 36.4 \\
\hline S-5 & 412 & 206 & 54 & 54 & 54.1 & 0.0 & 0.0 & 295 & 0.0 & 0.125 & 33.1 \\
\hline S-6 & 560 & 280 & 157 & 252 & 54.1 & 103.1 & 198.1 & 295 & 71.3 & 0.125 & 27.5 \\
\hline S-7 & 462 & 231 & 102 & 102 & 102.1 & 0.0 & 0.0 & 295 & 0.0 & 0.125 & 29.3 \\
\hline S-8 & 580 & 290 & 148 & 171 & 102.1 & 45.8 & 69.2 & 295 & 31.7 & 0.125 & 33.5 \\
\hline
\end{tabular}

*1 斜めひび割れ角度の実測值で, 図-27 中の 2 点の矢印を結んだ直線と部材軸とのな寸角度

なっており，斜めひび割れの角度を考慮してもなお安全 側の評価になっている. 鋼繊維を混入した供試体では, 発生した斜めひび割れに鋼繊維が架橋し，鋼繊維がせん 断力を負担するため実験值が安全側の值になるものと考 えられる.

\section{f) 鋼繊維が負担するせん断力 $V_{f}$}

鋼繊維が負担するせん断力 $V_{f}$ を UFC 指針に準拠し, 式(12)により算出し， $V_{f}$ を考慮したせん断而力の計算值 V*を式(13)により算出した.

$$
\begin{gathered}
V_{f . c a l}=\frac{f_{v}}{\tan \beta_{u}} \cdot b_{w} \cdot z \\
V_{\text {cal }}^{*}=V_{c . c a l}+V_{\text {s.cal }}+V_{f . c a l}
\end{gathered}
$$

ここに， $V_{\text {c.cal }}$ は式(8)による計算值， $V_{\text {s.cal }}$ は式(11)によ る計算值, $f_{v}$ は高強度䋊維補強モルタルの斜めひび割れ 直角方向の平均引張強度, $\beta_{u}$ は軸方向と斜めひび割れの な寸角度である，なお，今回の実験では $f_{v} を 2.2 \mathrm{~N} / \mathrm{mm}^{2}$ と仮定した. これは, 鋼纎維を 2.0vol.\%混入した UFC の $f_{v}$ が 8.8N/mm² であり ${ }^{5)}$, 今回の実験における鋼繊維の混

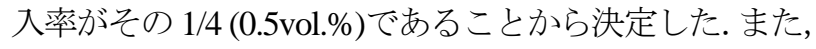
斜めひび割れの角度 $\beta_{u}$ は表-26 と同様の実測值とした.

鋼䋊維が負担寸るせん断力 $V_{\text {f.cal }}$ を考慮したせん断耐力 の計算值と実験值の比較を図-32 および表-27に示寸.鋼 繊維を混入した供試体のせん断而讨力の実測值は, 計算值 とほぼ対応しており，式(12)により鋼纎維が負担するせ ん断力 $V_{f}$ を考慮することで, せん断耐力は適切に評価さ れたといえる.

以上より，鋼繊維によるモルタルが負担するせん断力 $V_{c}$ の増加, 斜めひび割れの角度によるせん断補強鉄筋が 負担するせん断力 $V_{s}$ の増加, および鋼䋊維が負担するせ ん断力 $V_{f}$ を考慮することで, 高強度繊維補強モルタルを 用いたはり部材のせん断耐力を合理的に設計できると考 えられる.ただし，今回の実験結果のみではデータが少 ないため，現段階では，高強度繊維補強モルタルを用い たはり部材のせん断耐力は，コンクリート標準示方書に 準拠し，式(6)，式(9)および式(10)により行うのが現実的 と考えられる.

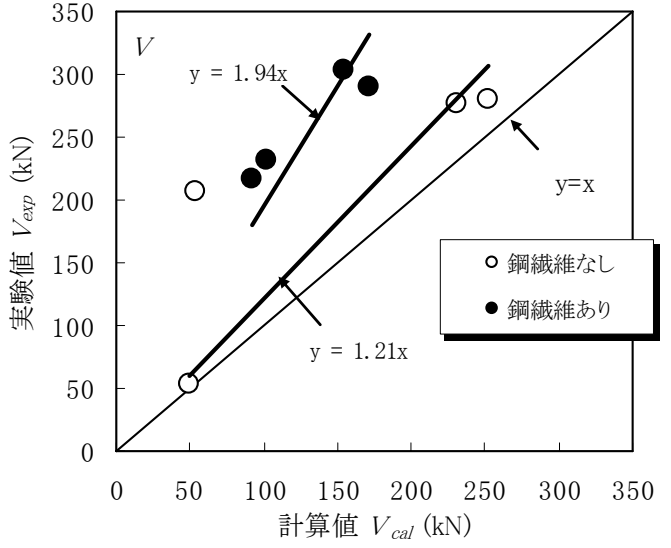

図-31 せん断耐力の実験值と計算值との比較 $\left(\beta_{u}\right.$ 考慮 $)$

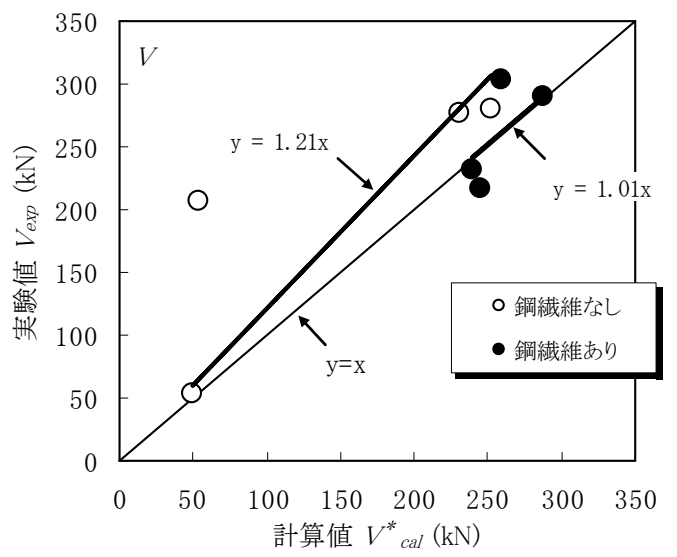

図-32 $V_{f . c a l}$ を考慮したせん断耐力の計算值と実験值の比較

\begin{tabular}{|c|c|c|c|c|c|c|c|}
\hline \multirow[b]{2}{*}{ 供試体 } & \multicolumn{2}{|c|}{ せん断耐力 $V^{*}$} & \multirow[b]{2}{*}{$\begin{array}{l}\text { 式(8) } \\
V_{\text {c.cal }} \\
(\mathrm{kN})\end{array}$} & \multirow[b]{2}{*}{$\begin{array}{c}\text { 式(11) } \\
V_{\text {scal }} \\
(\mathrm{kN})\end{array}$} & \multirow[b]{2}{*}{$\begin{array}{c}\text { 式(12) } \\
V_{\text {facl }} \\
(\mathrm{kN})\end{array}$} & \multirow[b]{2}{*}{$\begin{array}{c}f_{v} \\
\left(\mathrm{~N} / \mathrm{mm}^{2}\right)\end{array}$} & \multirow[b]{2}{*}{$\begin{array}{c}\beta_{u_{u}}{ }^{11} \\
\left({ }^{\circ}\right)\end{array}$} \\
\hline & $\begin{array}{c}\text { 実験值 } \\
V_{\text {exp }} \\
(\mathrm{kN})\end{array}$ & $\begin{array}{c}\text { 計算值 } \\
V_{\text {cal }} \\
(\mathrm{kN})\end{array}$ & & & & & \\
\hline S-1 & 54 & 49 & 49.1 & 0.0 & 0.0 & - & 43.0 \\
\hline S-2 & 277 & 231 & 49.1 & 181.5 & 0.0 & - & 29.6 \\
\hline S-3 & 216 & 246 & 92.7 & 0.0 & 153.1 & 2.2 & 26.7 \\
\hline S-4 & 304 & 259 & 92.7 & 62.1 & 104.4 & 2.2 & 36.4 \\
\hline S-5 & 206 & 54 & 54.1 & 0.0 & 0.0 & - & 33.1 \\
\hline S-6 & 280 & 252 & 54.1 & 198.1 & 0.0 & - & 27.5 \\
\hline S-7 & 231 & 239 & 102.1 & 0.0 & 137.2 & 2.2 & 29.3 \\
\hline S-8 & 290 & 288 & 102.1 & 69.2 & 116.3 & 2.2 & 33.5 \\
\hline
\end{tabular}

表-27 $V_{\text {f.cal }}$ を考慮したせん断耐力と計算値との比較 


\section{6. 結論}

高強度繊維補強モルタルの PC 構造物一の適用性を検 討するため, 材料試験, PC はりの曲げ載荷試験およびせ 儿断載荷試験を実施した. 今回行った実験の範囲で得ら れた知見は以下のとおりである.

（1）高強度繊維補強モルタルの物性に関して

1）高強度繊維補強モルタルは水セメント比を $17 \%$ とす ることで設計基準強度 $120 \mathrm{~N} / \mathrm{mm}^{2}$ を実現できる.

2) 引張強度は, コンクリート標準示方書の引張強度算定 式で安全側に評価できる.

3) ヤング係数は同じ強度のコンクリートに比べ低く, 高 強度コンクリートを用いたPC構造物の設計施工規準 のヤング係数算定式を 0.85 倍とすることで評価でき る.

4) 曲げ強度は鋼繊維の混入率の増加に伴い大きくなる.

5) 蒸気養生直後から 1 年後までのクリープ係数は 0.75 程度であり, 1.0 以下であった.

6) 蒸気養生直後から 1 年後までの乾燥収縮ひずみは $400 \mu$ 程度であり, 普通コンクリートと同程度であっ た.

(2) 耐久性能に関して

1) 促進中性化試験では 2 年後においても中性化深さは 0mm であった.

2) 凍結融解試験では 480 サイクルの凍結融解の繰返し でも相対動弾性係数は低下せず，95\%以上であった.

3）浸せき法により測定した見掛けの塩分拡散係数は $0.0176 \mathrm{~cm}^{2}$ /年であり，飛沫帯，かぶり $35 \mathrm{~mm}$ の条件で も十分な耐久性を満足した。

(3) 曲げ特性に関して

1) 高強度繊維補強モルタルを用いたPCはりのひび割れ 荷重および曲け破壊荷重は，計算值を上回っており， 曲げひび割れ発生モーメントや曲げ耐力は通常の PC はりと同様の設計手法で安全側に評価できると考え られる。

2) 鋼繊維を混入していない供試体の荷重と変位の関係 および PC 鋼材のひずみは, 非線形解析とよく一致し ており,設定した材料非線形特性は鋼䋊維を混入しな い場合に関してはおおむね妥当であると考えられる. 鋼繊維を混入した場合の材料非線形特性に関しては, モルタルの引張軟化特性などを考慮し, 新たに検討す る必要がある。

3) 曲げ破壊時の終局ひずみは $4500 \mu$ 程度となり，モル タルの圧縮強度をヤング係数で除した值とほぼ一致 した.

4) 鋼繊維を混入することで，ひび割れ発生モーメント, 曲げ而力およびひび割れの分散性が向上した。また, 曲け破壊後の断面の状態も改善された.
5) 曲げ耐力を算出する際の応力ーひずみ曲線は直線と し, 終局ひずみに圧縮強度をヤング係数で除した值を 使用することで，曲げ耐力を適切に評価できる.

6) 鋼繊維を混入していない場合の曲げひび割れ幅は, コ ンクリート標準示方書の曲げひび割れ算定式とほぼ 一致した. 一方, 鋼綫維を混入した場合は, 鋼繊維の 混入によるひび割れ分散性の向上を考慮することで ひび割れ幅を適切に評価できた。

（4）せん断挙動に関して

1) 斜めひび割れ発生荷重およびせん断破壊耐力はコン クリート標準示方書に準拠して算出した計算值を上回 っており，せん断耐力は通常の PC はりと同様の手法 で安全側に評価できる。

2) 鋼繊維を混入することで, 斜めひび割れ発生荷重, お よびせん断破壊荷重の向上が認められた。

3）鋼繊維によるモルタルが負担寸るせん断力 $V_{c}$ の増加, 斜めひび割れの角度によるせん断補強鉄筋が負担す るせん断力 $V_{s}$ の増加，および鋼繊維が負担するせん 断力 $V_{f}$ を考慮することで, 高強度繊維補強モルタル を用いたはり部材のせん断耐力を適切に評価できた.

謝辞 : 本研究を行うにあたり宇部興産(株)の大西利勝氏, 宇部三菱セメント(株)の村田浩三氏，千葉博英氏，黒岩 義仁氏のほか，多くの皆様にご指導・ご支援をいただい た.ここに，ご協力いただいた関係各位に深く感謝の意 を表す。

\section{参考文献}

1) 三井健郎，小島正郎，高尾全，佐藤敏之 : 超高強度コンク リート新世代 一川崎・武蔵小杉での適用例(2) 設計基淮強度 $150 \mathrm{~N} / \mathrm{mm}^{2}$ 超高強度コンクリートによる超高層集合住宅の施 エー, セメント・コンクリート，No.723，pp.25-31，2007.5.

2) 陣内浩, 黒岩秀介, 寺内利恵子, 阿部剛士 : 超高強度コン クリート新世代 一川崎・武蔵小杉での適用例(1) 設計基淮強 度 $150 \mathrm{~N} / \mathrm{mm}^{2}$ の低収縮型超高強度コンクリートの製造と施工 THE KOSUGI TOWER一, セメント・コンクリート, No.723, pp.18-24, 2007.5.

3）日本コンクリート工学協会: 高強度コンクリート構造物の 構造性能研究委員会報告書・論文集，pp.16-21，2006.7.

4) 桜田道博, 大山博明, 森拓也, 二羽淳一郎 : 高強度繊維補 強モルタルを使用した PC 構造物, コンクリート工学, Vol.45, No.7, pp.46-53, 2007.7.

5) 土木学会 : 超高強度繊維補強コンクリートの設計・施工指 針(案)，コンクリートライブラリー113，2004.9.

6) 田中良弘, 福浦尚之, 鵜沢哲史, 坂本淳, 前堀伸平, 片桐 誠 : 超高強度繊維補強コンクリートの引張特性と引張軟化曲 線のモデル化，土木学会論文集，No.788／V-67, pp.159-173, 2005.5. 
7) 福浦尚之, 田中良弘，趙唯堅，柄登志彦，加納宏一，兵藤 彦次 : 超高強度繊維補強コンクリートはり部材の曲げ・せん 断載荷実験, 土木学会論文集, No.795／V-68, pp.67-80, 2005.8.

8) 福浦尚之, 田中良弘, 加納宏一 : 非線形有限要素解析によ る超高強度繊維補強コンクリートはり部材の挙動シミュレー ション，土木学会論文集，No.795／V-68，pp.81-93， 2005.8.

9) 坂本淳, 田中良弘，新藤竹文，宇治公隆：最大粒径 $2.5 \mathrm{~mm}$ の細骨材を用いたノンプレミックス型超高強度䋊維補強コン クリートに関する実験的研究，土木学会論文集 E, Vol.66, No.3, pp.325-336, 2010.9.

10) 雨宮美子, 桜田道博, 森拓也, 二羽淳一郎 : 超高強度䋊維 補強モルタルを用いた PC 梁の載荷実験, コンクリート工学 年次論文集，pp.1657-1662，2005.7.

11) 桜田道博, 雨宮美子, 大山博明, 森拓也: 高強度繊維補強 モルタルの材料特性, コンクリート工学年次論文集, Vol.29, No.2, pp.133-138, 2007.7.

12) 鵜澤正美, 山田一夫 : RPC を用いた超高強度・高じん性コ ンクリートの開発動向, コンクリート工学, Vol.39, No.2, pp.53-56, 2001.2.

13）武者浩透，大竹明郎，関文夫，大熊光，児玉明彦，小林忠 司 : 無機系複合材料(RPC)を用いた酒田みらい橋の設計と施 工，橋梁と基礎，Vol.36，No.11，pp.2-11，2002.11.

14) 黒岩正，岩㟝郁夫，大熊光 : 超高強度繊維補強コンクリー 卜を用いた国内初の道路橋一東九州自動車道堀越Cランプ橋 一, コンクリート工学, Vol.43, No.10, pp.39-44, 2005.10.

15) 武者浩透，一宮利通，芦田公伸，田中敏嗣 : 超高強度繊維 補強コンクリート(UFC)の耐久性と PC 構造物への適用, プレ ストレストコンクリート, Vol.52, No.2, pp.80-86, 2010.3.

16) Setra, AFGC: Ultra High Performance Fibre-Reinforced Concretes, pp.15-16, 2002.1.
17) 土木学会 : 鋼繊維補強コンクリート設計施工指針(案), コン クリートライブラリー第 50 号, 1983.3.

18) 土木学会 : 2007 年制定コンクリート標準示方書【施工編】, pp.82-83, 2008.3.

19) JIS 原案 : コンクリートの圧縮クリープ試験方法(案), コン クリート工学, Vol.23, No.3, pp.55-56, 1985.3.

20) プレストレストコンクリート技術協会 : 高強度コンクリー トを用いた PC 構造物の設計施工規準，2008.10.

21) 土木学会 : 2007 年制定コンクリート標準示方書【設計編】, 2008.3.

22) 桜田道博, 渡辺浩良, 大浦隆，鈴木基行 : 石炭灰を主原料 とする高性能人工骨材を用いた PC はり部材の力学的特性に 関する研究，土木学会論文集，No.774／V-65, pp.27-37, 2004.11.

23) 日本コンクリート工学協会 : 超流動コンクリート研究委員 会報告書，1994.

24) 土木学会 : JSCE-G572-2010 浸せきによるコンクリート中の 塩化物イオンの見掛けの拡散係数試験方法(案), コンクリー 卜標準示方書【規準編】，土木学会規準および関連規準, pp.319-323, 2010.11.

25) 日本道路協会 : 道路橋示方書・同解説，III コンクリート橋 編, pp.171-175，2002.3.

26) 小林一輔，星野富夫，辻恒平 : 海洋環境下における鋼繊維 補強コンクリートの鉄筋防食効果，土木学会論文集，No.414 〈V-12, pp.195-203, 1990.2.

27) 加納直樹 : 鋼繊維を混入した鉄筋コンクリートの曲げひび 割れ幅算定式, コンクリート工学, Vol.44, No.11, pp.58-62, 2006.11.

(2010. 10. 27 受付)

\title{
EXPERIMENTAL STUDY ON THE APPLICATION OF HIGH STRENGTH FIBER REINFORCED MORTAR TO PRESTRESSED CONCRETE STRUCTURES
}

\author{
Michihiro SAKURADA, Takuya MORI, Hiroaki OHYAMA and Hiroshi SEKI
}

In order to study the application of high strength fiber reinforced mortar which has design compressive strength $120 \mathrm{~N} / \mathrm{mm}^{2}$ to prestressed concrete structures, the authors carried out material tests, bending tests and shear tests of prestressed concrete beam specimens. From the material tests, we obtained material properties for the design of prestressed concrete structures such as compressive strength, tensile strength, Young's modulus, coefficient of creep, dry shrinkage and so on. The results of the bending tests and the shear tests of prestressed concrete beam specimen shows that experimental flexural strength and shear strength of prestressed concrete beam using high strength fiber reinforced mortar exceeds strength calculated by traditional design method. It is confirmed that high strength fiber reinforced mortar can be applied to prestressed concrete structures. 